\title{
Risk Attitudes and Investment Decisions across European Countries - Are Women More Conservative Investors than Men?
}

\author{
Oleg Badunenko, Nataliya Barasinska, Dorothea Schäfer部
}

This draft: January 20, 2010

\begin{abstract}
This study questions the popular stereotype that women are more risk averse than men in their financial investment decisions. The analysis is based on micro-level data from large-scale surveys of private households in five European countries. In our analysis of investment decisions, we directly account for individuals' self-perceived willingness to take financial risks. The empirical evidence we provide only weakly supports the gender differences argument. We find that women are less likely to invest in risky financial assets. However, when the probability of investing is controlled for, males and females are found to allocate equal shares of their wealth to risky assets.
\end{abstract}

Keywords: gender, risk aversion, financial behavior JEL Classification: G11, J16

*DIW Berlin, Mohrenstr. 58, 10117 Berlin, Germany. Tel.: +49-30-897-89-203. Fax: +49-30-89789-104. Email: nbadunenko@diw.de

†DIW Berlin, Mohrenstr. 58, 10117 Berlin, Germany. Tel.: +49-30-897-89-691. Fax: +49-30-89789-104. Email:nbarasinska@diw.de

Corresponding author. DIW Berlin, Mohrenstr. 58, 10117 Berlin, Germany. Tel.: +49-30-897-89-162. Fax: +49-30-89789-104. Email: dschaefer@diw.de

${ }^{\S}$ Financial support from the European Commission $\left(7^{\text {th }}\right.$ Framework Programme, Grant Agreement No. 217266) is gratefully acknowledged. We thank Alexander Muravyev and Alfred Steinherr for helpful comments and suggestions. We are also grateful to Michael Viertel for excellent research assistance. 


\section{Introduction}

It is commonly believed that men are more willing to take financial risks than their female counterparts. In fact, numerous empirical studies provide evidence of systematic differences in financial risk-taking between men and women (e.g., Bajtelsmit et al. (1996), Dwyer et al. (2002), Hartog et al. (2002), Fellner \& Maciejovsky (2007), Agnew et al. (2008), Borghans et al. (2009)). Nevertheless, the existing evidence seems insufficient to consider women as conservative investors.

First of all, there are studies that question the prevailing belief and provide evidence that gender has no effect on individuals' investment decisions (e.g., Johnson \& Powell (1994), Schubert et al. (1999), Keller \& Siegrist (2006) and Booth \& Nolen (2009)). Furthermore, most evidence supporting the gender stereotype is based on data from the United States. Yet, given cross-country differences in macroeconomic conditions, institutional settings and social policies, results obtained for one country should not be automatically generalized for the rest of the world. There are only few empirical studies investigating the investment decisions of males and females outside the US. For instance, Palsson (1996) uses survey data on Swedish households, while Perrin (2008) employs survey data on Swiss households.

Secondly, there is still no consensus in the literature regarding the determinants of gender differences in financial behavior. One hypothesis is that females make more conservative investment decisions because they are, by nature, more risk averse than males. This conjecture is supported by a range of studies that look at individual specific attitudes towards risk taking (Jianakoplos \& Bernasek (1998), Donkers \& van Soest (1999), Hartog et al. (2002), Dohmen et al. (2006) and Perrin (2008)). These studies find that being a man is positively correlated with willingness to take risks in financial matters. A direct test 
of the hypothesis is, however, hardly possible since it requires two sets of information: the actual investment behavior of individuals and their risk attitudes. The latter set of information is rarely available. Instead one can use individuals' self-assessment of their willingness to take financial risks and combine it with their real-life investment decisions. As shown by Wärneryd (1996) and Dohmen et al. (2006), self-declared attitudes towards risk-taking reflect the true risk preferences of individuals and, therefore, present reliable instruments in this instance.

The aim of the present study is to investigate investment behavior of males and females in five European countries: Austria, Cyprus, Germany, Italy and the Netherlands. Specifically, we consider two aspects of investment behavior. Firstly, we ask whether, all things equal, men and women have the same probability of investing in risky financial assets. Secondly, for individuals who own risky assets, we analyze differences in the shares of wealth invested by men and women in these assets. Furthermore, we ask whether differences in investment behavior can be explained by gender-specific differences in risk attitudes. In other words, the aim is to test the hypothesis that female investors take less risks than their male counterparts because they are more risk averse by nature than men.

Our analysis is based on microeconomic data drawn from national surveys of private households. The data allow us to control for a wide range of individual-specific characteristics that may be relevant for investment decisions. Most importantly, we can directly control for individuals' attitudes towards risk-taking, because our data contain information on respondents' self-assessment on his or her willingness to take financial risks. Moreover, the cross-country nature of the data allows us to see whether behavioral patterns are common for all five countries despite differences in institutional settings, social policies, and other country specific factors. 
The results of the analysis show that women are indeed less likely to hold risky financial assets than their male counterparts. However, conditional on ownership, both gender groups seem to invest an equal share of their wealth in these assets, ceteris paribus. Furthermore, our results show that gender differences in portfolio choices cannot be attributed to differences in risk tolerance between the two groups. Even when we control for individual attitudes towards risk-taking, we find statistically significant differences between men and women (1) in the probability of investing in stocks and (2) in the portfolio shares allocated to stocks. Hence, the hypothesis that females take more conservative investment decisions because they are inherently more risk averse than males cannot be confirmed by the data.

The remainder of the paper is organized as follows. In the next section, we review the existing literature on gender differences in financial risk-taking. In Section 3, we formulate our working hypotheses and describe how the hypotheses are tested. The data employed to test the hypotheses are described in Section 4. In Section 5, we analyze the effects of gender on the probability of holding risky assets and on the share of wealth allocated to these assets. In Section 6, we examine whether gender effects disappear when controlling for individual risk attitudes. The last section concludes.

\section{Gender and investment decisions: What do we know?}

The relationship between investment decisions and investors' socioeconomic and demographic characteristics receives considerable attention in academic literature. Gollier (2002) predicts that under the assumption of a frictionless market, investors' wealth, age, investment horizon, human capital, and even family composition play a role in portfolio choice and, thus, should be introduced into the models of portfolio decision. Further- 
more, Guiso et al. (2003) argue that in imperfect markets, investors' individual-specific factors play an important role; especially important are factors that are negatively correlated with participation costs. For example, better-educated individuals incur lower information costs, which are a part of participation costs.

Still, there is no consensus regarding the role of gender in investment behavior. Some studies predict that, ceteris paribus, there are no differences between men and women in financial decision-making. Johnson \& Powell (1994) explore differences in the decisions taken by individuals with managerial education. They find that males and females in this subpopulation display similar risk propensity. Although this finding cannot be generalized to the total population, it may indicate that educational background plays an important role in offsetting gender differences in risk taking. In a more general context, based on the Panel Study of Income Dynamics, Haliassos \& Bertaut (1995) find that sex has no effect on an investor's decision to hold stocks. Also, the results of a recent study by Keller \& Siegrist (2006) based on a representative survey of private households in Switzerland show that females have the same willingness to invest in stocks as males.

Nonetheless, the above-mentioned literature is significantly outnumbered by studies claiming that gender matters. For instance, it is argued that female investors are less willing to hold risky assets and, conditional on the decision to hold them, invest a smaller share of their wealth into these assets than their male counterparts. One of the early studies representing this view is conducted by Hinz et al. (1996). Using data on investment decisions of 500 participants of a defined contribution retirement plan in the USA, they find that men are more likely to hold risky assets than women and that the percentage of wealth invested by men in these assets is higher than that invested by women. Similar evidence is provided by Barsky et al. (1997), who show that males invest a higher fraction of their financial wealth in stocks, while women prefer safer assets such as Treasury 
bills and savings accounts. Bajtelsmit et al. (1996) investigate what factors influence the percentage of wealth invested in risky assets in a defined contribution retirement plan in 1989 in the USA. They too find that women are relatively more risk averse than men. The results of the study may, however, be biased by the fact that it is not known whether the individuals themselves or their employers made the allocation decision. Jianakoplos \& Bernasek (1998) test gender differences in investment behavior using a large data set drawn from the Survey of Consumer Finances (CFS) 1989. The analysis reveals that single women are relatively more risk averse than single men or married couples.

Numerous experimental studies are consonant with literature that builds upon survey data. Powell \& Ansic (1997), for instance, find that men have a significantly higher preference for risk than women: males prefer "riskier" investment strategies in order to achieve the highest gains, while women select "safer" strategies that allow them to avoid the worst possible losses. Olsen \& Cox (2001), who investigate the gender differences for professionally trained investors, find that women weigh risk attributes, such as possibility of loss and uncertainty, more heavily than men. Female investors also tend to emphasize risk reduction more than their male colleagues. Consonant with these findings, Dwyer et al. (2002) and Niessen \& Ruenzi (2007) show that, for managers of US mutual funds, gender differences are significant even when educational background and work experience are comparable. Finally, Fellner \& Maciejovsky (2007) find that women prefer less volatile investments and exhibit lower market activity. For example, they submit fewer offers and engage less often in trades.

As an explanation for gender differences in observed investment behavior, it is commonly suggested that females are more risk averse by nature than males. This conjecture is supported by a number of studies that investigate the differences between the two gender groups with respect to individual specific attitudes towards risk taking. Jianakoplos 
\& Bernasek (1998) analyze data on respondents' self-assessed tolerance towards investment risk and find that women perceive themselves as less inclined to risk-taking than men. Also Donkers \& van Soest (1999), who use a survey of Dutch households containing questions on perceived risk aversion, find that being a women significantly increases the degree of risk aversion. Similar evidence is found in experimental lotteries by Hartog et al. (2002), who deduce individuals' Arrow-Pratt measure of risk aversion. Two more recent studies provide evidence on gender differences in individual risk preferences based on large surveys of private households. One of the studies is conducted by Dohmen et al. (2006), who use data of the German Socioeconomic Panel (SOEP); another is done by Perrin (2008), who surveys a large sample of Swiss households. Both studies find that being a man is positively correlated with the willingness to take risks in financial matters.

Although abundant, the existing evidence is insufficient in two important respects. Firstly, the decision to invest in risky assets needs to be analyzed as a two-step procedure in which a self-selection problem occurs. An investors will naturally decide initially whether it pays at all to invest in risky assets. This is the participation decision. For example, sunk upfront information costs may deter the individual from considering risky investments. Once the individual has overcome this barrier and is willing to participate, the next step is to decide how much of the wealth should be allocated to the risky investment. This is the allocation decision. The outcome of both stages needs to be considered for assessing whether women are more conservative investors than men. A cross-country approach - as utilized in this paper - may give additional insights since institutional factors specific to a country may significantly influence investment decisions.

Secondly, for proving that differences in investment behavior of men and women are indeed caused by the inherent tendency of women to be more risk averse, a control variable capturing individual risk preferences should be included into the model of invest- 
ment choice, along with gender and other socioeconomic variables. If the gender variable loses its explanatory power in this expanded setting, one can conclude that the inherent tendency of female investors to be more risk averse than their male counterparts is indeed the reason for observed differences. Our study provides new insights in both important respects. The approach is described in more detail below.

\section{Research hypotheses and test methodology}

The analysis of the investment process of private household heads requires clear definitions. The participation decision is the decision to hold or not to hold risky financial assets. The allocation decision refers to the fraction of disposable financial wealth invested in risky financial assets. The test of an inherently higher risk aversion of women examines initially whether sex has a significant effect on investment decisions after controlling for investors' financial wealth, income, age, education and a range of other socioeconomic variables. We explicitly omit individual attitudes towards financial risk in this setting. ${ }^{1}$ Under this specification, we expect to find a significant effect of sex. Then, in the second step, we extend the model by including the individual willingness to take financial risks as an additional explanatory variable. In this case, we expect to find no gender effects because we control for all potential sources of gender differences in investment behavior. Respectively, we set up two pairs of hypotheses. Each pair refers to both the participation and the allocation decision.

Hypothesis 1a: Ceteris paribus, women are less likely to invest in risky financial assets than men if the individual's willingness to take financial risks is omitted.

\footnotetext{
${ }^{1}$ In our choice of control variables, we follow the existing empirical literature on household financial behavior. See, e.g. Haliassos \& Bertaut (1995) and Guiso et al. (2003).
} 
The participation decision is modeled in the following manner. Denote $U_{r}$ as the individual utility of holding risky assets and $U_{s}$ as the utility of not holding risky assets. An investor decides to hold risky financial assets if $U_{r}-U_{s}>0$. Neither utility is observable, but both are assumed to be functions of investors' socioeconomic and demographic characteristics:

$$
U_{s}-U_{r}=\alpha+\beta_{1} \text { Male }+\gamma_{1} x_{1}+e,
$$

where Male is a binary variable equal to 1 if the decision-maker is male, and 0 if female; $x_{1}$ is a vector of control variables and $e$ captures the unobserved factors. Then, if we define an indicator variable $Y$ equal to 1 if an individual owns risky assets and 0 otherwise, the probability of this choice conditional on the investor's observed characteristics is:

$$
\operatorname{Pr}[Y=1]=\alpha+\beta_{1} \text { Male }+\gamma_{1} x_{1}+e .
$$

We estimate the effects of explanatory variables by fitting empirical data to equation (1) and performing a probit regression. ${ }^{2}$ Hypothesis 1 a will be confirmed if we find a statistically significant positive coefficient on the variable Male.

Hypothesis 1b: All things being equal, women allocate a smaller share of their financial wealth to risky assets than men, conditional on the probability of investing in these assets.

To test this hypothesis, we estimate the effects of gender on the allocation decision. The investors' allocation decision is modeled based on the predictions of Haliassos \& Bertaut (1995). They show that, in frictionless markets and in the absence of transaction costs, a utility maximizing investor should always be willing to invest a positive amount of wealth in a risky asset when risky assets offer a higher expected return than risk-free

\footnotetext{
${ }^{2}$ We do not address the issue of potential endogeneity of the explanatory variables.
} 
assets. In the presence of participation costs, however, not all investors will be able to participate in the market of risky financial assets. More precisely, an investor will not participate in the market if utility gained from owning risky financial assets is smaller than the incurred participation costs. ${ }^{3}$

Because of the non-random sorting of individuals into participants and non-participants, we have to deal with a sample selection problem. Under these circumstances, a conventional linear regression model estimated by ordinary least squares is not a suitable tool for the analysis. Instead, we estimate the effect of gender on the share allocated to risky assets using Heckman's two-stage estimation procedure. ${ }^{4}$ The selection mechanism is modeled in the following manner. Let the equation that determines the sample selection have the form

$$
\operatorname{Pr}[Y=1]=\alpha+\beta_{1} \text { Male }+\gamma_{1} x_{1}+e,
$$

where $x_{1}$ is a set of control variables that affect the probability of participation in the market of risky financial assets, $\operatorname{Pr}[Y=1]$. This probability is estimated using a probit regression model. The equation describing the fraction of wealth invested in risky assets, $y^{*}$, is given by

$$
y^{*}=\beta_{2} \text { Male }+\gamma_{2} x_{2}+u,
$$

\footnotetext{
${ }^{3}$ Under participation costs, we understand all fixed and variable costs associated with market entrance and transactions, as well as information costs incurred by individuals while selecting and managing their financial portfolios.

${ }^{4}$ A popular strategy among the existing studies that look at the determinants of the fraction of wealth invested in risky financial assets is to use a Tobit regression model in order to deal with the lower bound (zeros) and the upper bound (ones) of the distribution of the wealth fraction, e.g. Jianakoplos \& Bernasek (1998), Bernasek \& Shwiff (2001) or Perrin (2008). However, according to Maddala (1991), the Tobit regression model is not appropriate for situations were the dependent variable is bounded between 0 and 1 by definition. There is no way a fraction of a wealth can be negative or higher than 1 . Furthermore, the Tobit model does not allow to correct for sample selection bias. Therefore, we do not apply Tobit in our study.
} 
where $y^{*}$ is a latent variable observed only if $\operatorname{Pr}[Y=1]>0$ and $x_{2}$ is a set of control variables affecting the allocation decision. Then, the model that describes the fraction of wealth observed in our sample - denoted as $y$ - has the form

$$
y \mid \operatorname{Pr}[Y=1]>0=\beta_{2} \text { Male }+\gamma_{2} x_{2}+\rho_{u e} \sigma_{u} \lambda+u,
$$

where $\rho_{u e}$ is the coefficient of correlation between $u$ and $e ; \sigma_{u}$ is the standard deviation of $u$; and $\lambda$ is the inverse Mill's ratio estimated from the first stage probit regression. Hypothesis $1 \mathrm{~b}$ will be confirmed if the estimate of $\beta_{2}$ in equation (2) is positive and statistically significantly different from zero, which means that being a man has a positive effect on the fraction of wealth invested in risky financial assets.

Hypothesis 2a: Conditional on individual willingness to take financial risks, men and women invest in risky financial assets with equal probability.

To test this hypothesis we re-estimate model (1) by including an additional variable that captures the individuals' willingness to take financial risks. The model describing the participation decision is thus

$$
\operatorname{Pr}[Y=1]=\alpha+\delta_{1} \text { Male }+v_{1} \text { RiskTolerance }+\mu_{1} x_{1}+e,
$$

where Risk Tolerance is a set of dummy-variables capturing the level of individual willingness to take financial risk. If distinct risk attitudes of men and women determine the gender differences in investment choices, the inclusion of risk tolerance into the regression should render the effects of the gender variable insignificant. Otherwise, if the coefficient of the dummy-variable Male remains significant, hypothesis 2a will rejected, and we can conclude that the observed differences in investment decisions are driven by other factors. 
Hypothesis 2b: Conditional on willingness to take financial risks, men and women invest equal shares of their financial portfolios in risky assets.

This hypothesis is tested by estimating the model of allocation decisions which explicitly controls for individual willingness to take financial risks. Similar to the test of Hypothesis $1 \mathrm{~b}$, we conduct Heckman's two-stage procedure to estimate the effects of gender on allocation decisions:

$$
y \mid \operatorname{Pr}[Y=1]>0=\delta_{2} \text { Male }+v_{2} \text { RiskTolerance }+\mu_{2} x_{2}+\rho_{u e} \sigma_{u} \lambda+u,
$$

Hypothesis $2 \mathrm{~b}$ will be confirmed if the coefficient on the gender variable becomes insignificant once we control for risk attitudes. Otherwise, the hypothesis will be rejected.

\section{Data and definitions}

To test our hypotheses, we employ cross-sectional data on private households from five European countries: Austria, Cyprus, Germany, Italy and the Netherlands. The data are assembled from several sources. German and Dutch data are drawn directly from the countries' national surveys: the German Socioeconomic Panel (SOEP) and the DNB Household Survey. Data for the other three countries are drawn from the Luxembourg Wealth Study (LWS) database. The year when each survey was conducted and the number of households covered are reported in Table 1.

Dealing with household-level data raises an important question about who makes investment decisions in multi-person households. Ideally, one should identify who is the

primary (or dominant) decision-maker in a household as is done by Bernasek \& Shwiff (2001). However, due to the specifics of our data, we are only able to identify who is the 
household head in a given household. The definition of household head varies across surveys; Table 2 summaries survey-specific definitions. The German and the Dutch data additionally allow us to identify whether the household head is the main decision-maker in financial matters. For the other three countries, we assume that the household head is the decision-maker. We also assume that investment decisions in a multi-person household are made by its head. Respectively, all demographic information used in the analysis refers to the household heads. Information on wealth and income is aggregated at household level. Descriptive statistics of the variables by country are found in Table 4 .

Another question that emerges is what asset holdings should be considered as risky? First of all, we should emphasize that this study focuses only on financial assets. Furthermore, the information collected in the national surveys allows us to differentiate among five asset classes: savings deposits, life insurance policies, bonds, stocks and investment funds. ${ }^{5}$ If one considers volatility of returns as the main source of risk, then only the last two asset types should be referred to as risky assets. Thus, our definition of risky assets comprises directly-held stocks and investment funds. The latter are included in the definition because an increasing number of households own stocks through investment funds, and ignoring these indirect holdings may lead to an underestimation of total stock holdings. On the other hand, risk content of mutual funds can vary significantly depending on the mix of asset types in a fund. For this reason, we also test hypotheses 1a through $2 \mathrm{~b}$ with directly-held stocks as a dependent variable.

\footnotetext{
${ }^{5}$ German survey does not differentiate between direct and indirect stockholding.
} 


\section{Analysis of participation and allocation decisions}

\subsection{Effects of gender on the probability of holding risky assets}

We start by comparing the participation of men and women in the market of risky financial assets. Figure 1 shows the fraction of male and female owners of risky assets per country. Apparently, there are well-pronounced differences between the two gender groups in all five countries. In particular, the largest difference is observed in Cyprus: the portion of male owners is 15 percent higher than the portion of female owners. The smallest difference is found in the Netherlands: the portion of males is 5 percent higher than the portion of females. As far as the direct ownership of stocks is concerned, the gender gap in participation is also substantial. The largest difference is observed in Cyprus (15 percent) and the smallest in Italy (6 percent). ${ }^{6}$ Thus, the figures on participation rates are in line with the popular belief that women are less willing to bear investment risks.

Now, we test Hypothesis 1a by estimating the effects of gender on the probability of holding risky assets. For this purpose, we estimate equation (1) by performing a probit regression. ${ }^{7}$ The dependent variable in this specification is a dummy-variable equal to 1 if a household owns risky assets and 0 otherwise. Effects of gender are captured by the dummy-variable Male, which is equal to 1 if the decision-maker is a man, and 0 if a female. We control for various socio-economic characteristics such as income, financial wealth, age, education, employment, marital status, number of children, and ownership of real estate. A set of wealth-quartile dummies and a set of age-bracket dummies is used to allow for nonlinearities in the effects of wealth and age. The base category for wealth

\footnotetext{
${ }^{6}$ In the German data, ownership of stocks cannot be disentangled from other risky assets.

${ }^{7}$ We also estimated the equation using a logit regression model. The log-likelihood for the probit model is, however, higher than for the logit model in all five countries, favoring the probit model.
} 
is the first wealth quartile; the base category for age is the youngest group of individuals below the age 30 . The regression equation is estimated separately for each country.

Table 5 presents the estimation results. The effects are calculated at sample mean values for continuous variables and at zero for dummy-variables. The coefficients on the gender dummy variable Male are positive and statistically significant from zero only in three countries: Austria, Cyprus, and Italy. Ceteris paribus, males are about 7 percent more likely to hold risky assets than females in Austria and Cyprus. In Italy, the predicted difference in probabilities is about 2 percent. In Germany and the Netherlands, the gender of household heads seems to have no significant effect on the participation decision.

The predicted relationship for Austria, Cyprus, and Italy is generally in line with the common belief and, in that sense, does not present any novel evidence. Yet, there is an aspect that deserves more consideration. We are not able to identify whether a household head or his/her spouse is the decision-maker in Austria, Cyprus, and Italy. This data deficiency should, in fact, bias our results towards finding no significant differences between males and females. However, no evidence for gender differences is found only for Germany and the Netherlands, the two countries where survey data allows the most accurate identification of the decision-maker within a household.

How can this puzzling result be explained? The survey-specific definitions of a "household head" in Austria, Cyprus, and Italy are such that for most couples, the male partner will be inevitably identified as the "head", since income generated by a male would normally account for a larger part of household income. As a result, the percentage of female household heads is higher among single-person households, and the percentage of male household heads is higher among married couples. Indeed, the descriptive statistics in Table 4 reveal that the proportion of single females in Austria, Cyprus, and Italy is more than three times higher than the proportion of single males, while in the German and 
Dutch samples, the number of single females is only twice as high as the number of single males. Hence, the Austrian, Cypriot, and Italian samples of female-headed households are over-represented by single women. Previous research has identified this group as being more reluctant to take financial risks than male singles or married female household heads. ${ }^{8}$ Thus, overrepresentation of single women in the share of female-headed households may drive the significance of the positive effect of gender in the findings for Austria, Cyprus, and Italy.

There is also the possibility that the insignificant effects of gender found for Germany and the Netherlands may be the result of some distortion. As mentioned before, the definition of risky financial assets includes both direct stockholding and shares of investment funds. The risk of the latter can be quite small because of diversification. That might be the reason why women have been found as equally willing as men to invest in such assets. Exploration of this possibility requires estimation of the effect of gender on the probability of direct stockholding only. We estimate model (1) once again for all countries except Germany. ${ }^{9}$ The dependent variable is a dummy equal to 1 if a household owns only directly held stocks and 0 otherwise. The results are reported in Table 6 . The coefficients of the variable Male suggest that in all considered countries, men are on average more likely to own stocks than women. Hence, the results are sensitive to the definition of risky assets. This becomes especially clear in the case of the Netherlands where gender of the decision-maker has a significant effect on the probability of holding stocks, but not on the probability of holding stocks and investment funds. The magnitude of the esti-

\footnotetext{
${ }^{8}$ Jianakoplos \& Bernasek (1998) show that, of all household types, single women are the most risk averse. In particular, the fraction of wealth invested into risky assets by single women increases less than the fraction invested by single men or married women as household wealth increases. Single women also exhibit higher relative risk aversion than other groups over most periods of the life cycle. Moreover, in contrast to single men and married couples, single women reduce the portion of risky assets in their portfolios as the number of children increases.

${ }^{9}$ This specification cannot be estimated with German data, because in this survey, ownership of stocks cannot be disentangled from other risky assets.
} 
mates is, however, moderate: the difference in predicted probabilities between males and females ranges from 1 percent in Italy to 7 percent in Cyprus.

To summarize, Hypothesis 1a can be confirmed only in cases where the decisionmaker could not be accurately identified or when the definition of risky assets is narrowed to directly held stocks. However, even in those cases, where the effects of gender are found to be statistically significant, the magnitude of the estimated coefficients suggests that the influence of household heads' gender on the probability of owning risky assets is weaker than suggested by the figures obtained from the descriptive analysis in the preceding section. Variation in socioeconomic factors, especially in household wealth and income, seems to explain a great deal of differences in the decision to participate in the markets of risky financial assets.

\subsection{Effects of gender on the share of wealth allocated to risky assets}

Figure 2 shows the average share of risky assets conditional on the ownership of these assets. The shares are calculated separately for each gender group and country. We can perform the following analysis only on four countries. For Germany, information on the invested shares is unavailable. Female owners of risky assets seem to allocate an equal or even a slightly higher fraction of their financial wealth into risky assets than male owners. Only in the Netherlands, the average share held by men is higher than the share invested by women. A similar pattern is observed for shares invested in directly held stocks. The figures are somewhat surprising because most previous studies document that women usually invest lower shares of their financial portfolios into risky assets than males (e.g. Bajtelsmit et al. (1996), Barsky et al. (1997) and Jianakoplos \& Bernasek (1998)). 
To test Hypothesis $1 \mathrm{~b}$, we estimate the effects of gender on the share allocated to risky assets using the Heckman's two-stage estimation procedure. Our first-stage selection equation includes the same variables that were used in the probit regression for the participation decision. The choice of variables for the selection equation is in line with other empirical studies implementing Heckman's two-stage approach when analyzing shares of risky assets (see e.g. Guiso et al. (2003)). In the main equation, we include a natural logarithm of wealth instead of the dummies for wealth quartiles. The results of the estimation are documented in Table 7.

The main finding of the estimation is that gender seems to have very little effect on the allocation decision: in all four countries, the estimated coefficients on the variable Male are not significantly different from zero. Even when we focus on the shares of directly held stocks, we find a limited effect of gender on the allocation decision (see Table 8). Marginal effects of the variable Male appear to be significant only in Italy and the Netherlands, although, at low levels of significance. Hence, Hypothesis $1 \mathrm{~b}$ cannot be confirmed, at least not at high levels of statistical significance.

In conclusion, the findings show that differences between male and female investors with respect to allocation decisions are insignificant, especially when we consider the joint share of stocks and mutual funds in households' financial portfolios. Some weak evidence of differences is found when we limit our analysis to the share of wealth allocated to directly held stocks. Gender differences are more pronounced in the participation decision than in the allocation decision, even though the evidence there is not particularly strong. Next, we turn to the role of subjective attitudes towards financial risks. In particular, we explore whether the importance of gender for participation and allocation is affected by the inclusion of the previously omitted variable of self-declared risk tolerance into the regression analysis. 


\section{The role of individual attitudes towards financial risk}

\subsection{Measuring risk tolerance}

In each of the national surveys, respondents are asked to asses their own willingness to take financial risks. The exact formulation of the question and the scales on which the strength of the willingness is measured differ across surveys. Table 9 documents the respective questions asked in the national surveys. The German SOEP applies the most detailed scale, which contains 11 points, to measure the individuals' willingness to take risks in financial matters. In the Netherlands, a 7-point scale is applied. Finally, the Austrian, Cypriot, and Italian surveys, which use a 4-point scale, provide the least detailed information. ${ }^{10}$

To control for individual willingness to take financial risks in our regression analysis, we generate a set of dummy variables, RiskTolerance $j$, where $j$ indicates which alternative was selected by a respondent when answering the survey question about risk attitude. Table 10 describes the generated dummy variables. For example, for Austria, we generate four dummy variables: RiskTolerance 1 equal to 1 if the respondent chooses the first alternative and 0 otherwise, RiskTolerance 2 if the second alternative was selected and 0 otherwise, RiskTolerance 3 if the third alternative was selected and 0 otherwise, and RiskTolerance 4 if the fourth alternative was selected and 0 otherwise. In the same way, we generate the four dummy variables capturing the level of risk tolerance for Cyprus and Italy. The German and the Dutch data require special treatment because respondents

\footnotetext{
${ }^{10}$ While processing the data, we discovered that the Dutch and Italian data sets are characterized by high non-response rates to the question regarding willingness to take financial risk. For our analysis, nonresponses mean that all observations with missing data have to be excluded from the data set, which leads to a significant reduction of the data set. The non-response rate in the Dutch data set is 27 percent. The validity of the survey-based measures of self-declared risk tolerance is examined in laboratory experiments, and it is shown that they have a strong explanatory power for actual risk-taking behavior (see e.g. Dohmen et al. (2006) and Wärneryd (1996)).
} 
in the respective surveys were asked to asses their risk attitude on a more detailed ordinal scale. Therefore, we can generate eleven dummy variables for the German data set and seven dummy variables for the Dutch data set. However, taking into account that only a small number of respondents in both surveys chose the alternatives at the upper end of the scale, introducing all 11 or 7 dummies into a regression is not viable. Instead, we merge some of the alternatives so that the number of groups is reduced to four. Table 10 shows which alternatives were merged together in the cases of Germany and the Netherlands.

Figure 3 presents the distribution of males and females by the four groups depending on their willingness to take financial risk. In all countries, females clearly outnumber males in the group with the lowest risk tolerance. At higher levels of risk tolerance, the proportion of males exceeds the proportion of females, although the differences are not substantial. The coefficient of correlation between the variable Male and the categorical variable Risk Tolerance is positive and statistically significant in all five countries. The

coefficient amounts to 0.07 for Austria, 0.06 for Cyprus, 0.15 for Germany, 0.12 for Italy, and 0.14 for the Netherlands. The figures suggest that males tend to assess themselves as being more risk seeking than women. An important question that emerges is whether this correlation can explain why women are less likely to hold risky assets than men, even when they are equally wealthy.

\subsection{Effects of gender on the probability of holding risky assets when controlling for risk attitude}

In this section, we test Hypothesis 2a, which states that conditional on individual willingness to take financial risks, men and women invest in risky financial assets with equal 
probability. Firstly, we focus on the estimation of equation (3) where the dependent variable is an indicator variable equal to 1 if a household owns risky assets and 0 otherwise. The results of the estimation are found in Table 11.

The coefficients for the dummy variables RiskTolerance2, RiskTolerance3 and RiskTolerance4 should be interpreted in relation to the base category, RiskTolerance1, which denotes the lowest risk tolerance. For example, a positive coefficient on RiskTolerance4 means that a person with this level of risk tolerance is more likely to invest in risky assets as compared to an individual with the lowest level of risk tolerance. The estimated coefficients on all risk tolerance dummies in our model are plausible. They have a positive sign and the magnitude of the coefficients increases as the dummy variables indicate higher levels of risk tolerance. With respect to Germany and the Netherlands, the result confirms that our transformation of the original measure of risk attitude did not cause any biases. Nevertheless, to be on the safe side, we also estimate a model were the original survey measures are included, that is, eleven dummy variables for Germany and seven dummy variables for the Netherlands. However, the results remain unchanged. The only difference is that dummies for the higher levels of risk tolerance become insignificant.

Turning to the main variable of interest, the dummy variable Male, the obtained results are interesting from several perspectives. In Austria, the coefficient of Male remains statistically significant although the magnitude is lower in comparison to the results obtained after the estimation of model (1). Hence, although there is some positive correlation between being male and being risk tolerant, it does not completely explain the differences in the probability of holding risky assets by males and females.

In Cyprus, the gender effect is statistically insignificant. The effect was already only weakly significant when we did not control for risk attitudes. Thus, the results obtained for Cyprus show that the contribution of risk tolerance dummies to the explanation of 
gender differences is quite low. There is no difference in the participation decision between men and women in Cyprus if a high level of statistical significance is required. In contrast, the effect of gender in Italy increases in magnitude after we control for risk tolerance. This result, however, might be driven by the sample bias resulting from the high non-response rate to the risk attitude question described in the previous section. Finally, the most striking results are found for Germany and the Netherlands. Here, conditional on individual risk tolerance, the coefficients on the variable Male become negative. The negative sign suggests that males with the same risk tolerance as their female counterparts are less likely to invest in risky assets. It seems that women underestimate their willingness to take risks, since their actual behavior appears to be more risk-tolerant than what is expected from their stated risk tolerance. This conjecture, however, has not been studied in the literature yet. Guiso \& Paiella (2005) provide the only study we are aware of that finds a negative effect of being male on the probability of investing in risky assets when risk attitudes are taken into account. The authors, however, do not discuss the potential reasons for this finding.

Finally, we estimate the effects of gender and risk attitudes on the probability of investing in directly held stocks. Here too, we fit the data to a probit regression model. The estimation results are reported in Table 12. As we have seen from the estimation of model (1), gender has significant effects on the probability of stockholding when risk attitudes are not taken into account. Now, as we include risk tolerance dummies into the regression equation, the effects of gender seem to get weaker in all countries except for Italy. The coefficients on Male in Cyprus and the Netherlands become statistically insignificant. Thus, in these two, countries gender differences in the likelihood of investing in directly hold stocks in these two countries can be attributed to differences in risk tolerance between male and female household heads. 


\subsection{Effects of gender on the conditional share of risky assets when con- trolling for risk attitude}

The final step of our analysis is the test of the hypothesis that, conditional on willingness to take financial risks, men and women invest equal shares of their financial portfolios in risky assets. For this purpose, we include the risk tolerance measures into the regressions. Tables 13 and 14 document the results of estimation of model (4) for risky assets and for directly held stocks respectively. In previous sections, when we estimated the effects of gender on the invested shares without controlling for risk attitudes, we found no significant effect of gender on the share of total risky assets and some weak, but statistically significant, effect of gender on the share of directly held stocks in Italy and the Netherlands. The inclusion of risk attitudes into the regressions does not fundamentally change these results. In particular, for Austria and Cyprus, the coefficients on the variable Male remain insignificant. For Italy, the effect of gender becomes insignificant. In contrast, the Dutch data still predict a positive significant effect of being male on the portfolio share of directly held stocks.

Overall, two important findings emerge from our analysis of the allocation decision. Firstly, there is only weak evidence that gender matters at all for the decision about portfolio shares. Secondly, based on the results obtained for the Netherlands, we may conclude that subjective measures of risk tolerance do not help to explain differences between male and female investors where such differences are observed. Our findings suggest that gen-

der differences in portfolio choices can not be attributed to inherent gender-specific risk attitudes as it is commonly suggested. 


\section{Summary and conclusions}

In this paper, we question the popular stereotype that women are more risk averse in financial matters than men. While studying the behavior of the two gender groups, we advance the analysis of observed behavior by including subjective information on risk attitudes into our model of investment choice. Specifically, we link the actual investment decisions of individuals with their self-reported willingness to take financial risks.

The results of our analysis provide only partial evidence of gender differences. In particular, we find that women are less likely to hold risky assets than males, ceteris paribus. This relationship gets stronger when we focus on the ownership of directly held stocks. With respect to the allocation decision, however, the results of the regression analysis show that males and females invest equal shares of their wealth in risky financial assets, ceteris paribus. Only if we exclude investment funds from the class of risky assets and focus exclusively on directly held stocks, do we find that Italian and Dutch men hold higher shares of risky assets than their female counterparts. The observed irrelevance of gender for allocation decisions in a particular country is confirmed when we additionally control for individual attitudes towards risk-taking. However, in the cases where gender matters in the basic setting, it matters also when accounting for risk tolerance. This finding shows that if gender differences in portfolio choices exist, they cannot be attributed to differences in risk tolerance between the two groups. Other factors may play a role, such

as country-specific institutional factors, knowledge of financial markets, risk literacy or even trust in financial institutions. We leave the analysis of their impact on the portfolio decisions of female and male household heads to future research.

All in all, the results of the study, in particular the irrelevance of gender for the share of wealth allocated to risky financial assets, speak against the simplistic approach when sex 
is used as a proxy for risk aversion. Our findings also show that financial advice should be provided in accordance with individual risk preferences rather than be based on the stereotypical believes about behavior of a "typical" man or woman. 


\section{References}

Agnew, J. R., Anderson, L. R., Gerlach, J. R. \& Szykman, L. R. (2008), 'Who chooses annuities? an experimental investigation of the role of gender, framing, and defaults', American Economic Review 98(2), 418-22.

Bajtelsmit, V., Bernasek, A. \& Jianakoplos, N. (1996), 'Gender effects in pension investment allocation decisions', Center for Pension and Retirement Research pp. 145-156.

Barsky, R. B., Juster, T. F., Kimball, M. S. \& Shapiro, M. D. (1997), ‘Preference parameters and behavioral heterogeneity: An experimental approach in the health and retirement study', The Quarterly Journal of Economics 112(2), 537-79.

Bernasek, A. \& Shwiff, S. (2001), 'Gender, risk, and retirement', Journal of Economic Issues 35(2), 345-356.

Booth, A. L. \& Nolen, P. (2009), Gender differences in risk behaviour: Does nurture matter?, Discussion paper no. 4026., IZA.

Borghans, L., Golsteyn, B. H., Heckman, J. J. \& Meijers, H. (2009), Gender differences in risk aversion and ambiguity aversion, Working Papers 3985, IZA.

Dohmen, T., Falk, A., Huffman, D., Sunde, U., Schupp, J. \& Wagner, G. G. (2006), 'Individual risk attitudes: New evidence from a large, representative, experimentally-validated survey', DIW Discussion Paper, N 600 .

Donkers, B. \& van Soest, A. (1999), 'Subjective measures of household preferences and financial decisions', Journal of Economic Psychology 20(6), 613-642.

Dwyer, P. D., Gilkeson, J. H. \& List, J. A. (2002), ‘Gender differences in revealed risk taking: evidence from mutual fund investors', Economics Letters 76(2), 151-158. 
Fellner, G. \& Maciejovsky, B. (2007), ‘Risk attitude and market behavior: Evidence from experimental asset markets', Journal of Economic Psychology 28(3), 338-350.

Gollier, C. (2002), Household Portfolios, Cambridge, MA: MIT Press, chapter What Does Theory have to Say about Household Portfolios?

Guiso, L., Haliassos, M., Jappelli, T. \& Claessens, S. (2003), 'Household stockholding in europe: Where do we stand and where do we go?', Economic Policy 18(36), 125-170.

Guiso, L. \& Paiella, M. (2005), The role of risk aversion in predicting individual behavior, Temi di discussione (Economic working papers) 546, Bank of Italy, Economic Research Department.

Haliassos, M. \& Bertaut, C. C. (1995), 'Why do so few hold stocks?', The Economic Journal 105(432), 1110-1129.

Hartog, J., Ferrer-i Carbonell, A. \& Jonker, N. (2002), 'Linking measured risk aversion to individual characteristics', Kyklos 55(1), 3-26.

Hinz, R. P., McCarthy, D. D. \& Turner, J. A. (1996), Are women conservative investors? gender differences in participant directed pension investments, Pension Research Council Working Papers 96-17, Wharton School Pension Research Council, University of Pennsylvania.

Jianakoplos, N. A. \& Bernasek, A. (1998), 'Are women more risk averse?', Economic Inquiry $36(4), 620-30$.

Johnson, J. \& Powell, P. (1994), ‘Decision making, risk and gender: Are managers different?', British Journal of Management 5, 123-138. 
Keller, C. \& Siegrist, M. (2006), 'Investing in stocks: The influence of financial risk attitude and values-related money and stock market attitudes', Journal of Economic Psychology 27(2), 285-303.

Maddala, G. S. (1991), 'A perspective on the use of limited-dependent and qualitative variables models in accounting research', The Accounting Review 66(4), 788-807.

Niessen, A. \& Ruenzi, S. (2007), 'Sex matters: Gender differences in a professional setting', Working Paper Series .

Olsen, R. A. \& Cox, C. M. (2001), 'The influence of gender on the perception and response to investment risk: The case of professional investors', Journal of Behavioral Finance 2(1).

Palsson, A.-M. (1996), 'Does the degree of relative risk aversion vary with household characteristics?', Journal of Economic Psychology 17(6), 771-787.

Perrin, P. J. (2008), Geschlechts- und ausbildungsspezifische Unterschiede im Investitionsverhalten, Berner betribswirtschaftliche Schriften, Band 39, Haupt Verlag AG.

Powell, M. \& Ansic, D. (1997), 'Gender differences in risk behaviour in financial decisionmaking: An experimental analysis', Journal of Economic Psychology 18(6), 605-628.

Schubert, R., Brown, M., Gysler, M. \& Brachinger, H. W. (1999), 'Financial decisionmaking: Are women really more risk-averse?', American Economic Review 89(2), 381385.

Wärneryd, K.-E. (1996), 'Risk attitudes and risky behavior', Journal of Economic Psychology 17(6), 749-770. 


\section{Appendix}

Table 1: Sources of microeconomic data employed in the study

\begin{tabular}{lccccc}
\hline & Austria & Cyprus & Germany & Italy & Netherlands \\
\hline \multirow{2}{*}{$\begin{array}{l}\text { Survey } \\
\text { LWS }\end{array}$} & LWS & SOEP & LWS & DNB Household Survey \\
Year of survey & 2004 & 2002 & 2004 & 2004 & 2004 \\
No of households surveyed & 2,556 & 895 & 11,796 & 8,012 & 2,048 \\
\hline
\end{tabular}

Table 2: Definitions of household head

\begin{tabular}{ll}
\hline Country & Definition of household head \\
\hline Austria & $\begin{array}{l}\text { A self-declared household head or a household member with the most ac- } \\
\text { curate knowledge about the household finances }\end{array}$ \\
Cyprus & $\begin{array}{l}\text { Economically dominant member or primary economic unit of a household } \\
\text { Germany }\end{array}$ \\
& $\begin{array}{l}\text { Person who knows best about the general conditions under which the } \\
\text { household functions and is primarily responsible for the management of } \\
\text { household money }\end{array}$ \\
Italy & $\begin{array}{l}\text { Person primarily responsible for the household budget } \\
\text { Netherlands }\end{array}$ \\
& $\begin{array}{l}\text { Person who declares him-/herself as a household head and has the highest } \\
\text { influence on financial decisions of the household }\end{array}$ \\
\hline
\end{tabular}


Table 3: Definition of variables used in the analysis

\begin{tabular}{|c|c|}
\hline Variable & Definition \\
\hline Risky Assets & $\begin{array}{l}\text { Dummy variable equal to } 1 \text { if a household owns risky financial assets and } 0 \text { other- } \\
\text { wise. Risky financial assets include shares of national and foreign companies held } \\
\text { directly or through investment funds. }\end{array}$ \\
\hline Share & Fraction of a household's portfolio allocated to risky financial assets. \\
\hline Stocks & $\begin{array}{l}\text { Dummy variable equal to } 1 \text { if a household owns directly held stocks and } 0 \text { other- } \\
\text { wise. }\end{array}$ \\
\hline Stocks Share & Fraction of a household's portfolio allocated to directly held stocks. \\
\hline Income & Household's net annual income in Euros. \\
\hline Financial Wealth & $\begin{array}{l}\text { Household's total financial wealth. It takes into account holdings in saving de- } \\
\text { posits, bonds, stocks and mutual funds. }\end{array}$ \\
\hline Real Property & $\begin{array}{l}\text { Dummy variable equal to } 1 \text { if the household owns residential real estate and } 0 \\
\text { otherwise. }\end{array}$ \\
\hline Employed & $\begin{array}{l}\text { Dummy variable equal to } 1 \text { if the household head has a full- or part-time job and } \\
0 \text { otherwise. }\end{array}$ \\
\hline Self-Employed & Dummy variable equal to 1 if the household head is self-employed. \\
\hline Retired & Dummy variable equal to 1 if the household head is retired. \\
\hline University & $\begin{array}{l}\text { Dummy variable equal to } 1 \text { if the household head has a university degree and } 0 \\
\text { otherwise. }\end{array}$ \\
\hline No of children & Number of children under 18 in a household. \\
\hline Age & Age of a household head; a continuous variable. \\
\hline Male & Dummy variable equal to 1 if the household head is male, 0 if female \\
\hline Single & Dummy variable equal to 1 if the household head is a single person, 0 otherwise. \\
\hline
\end{tabular}

Figure 1: Fraction of male and female owners of risky assets

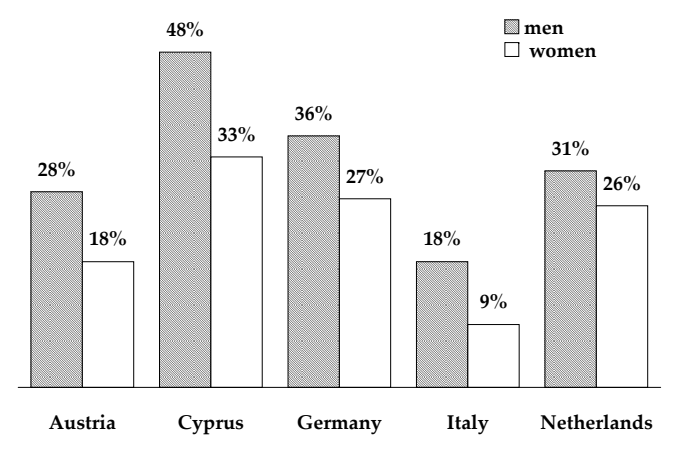

a) Total risky financial assets

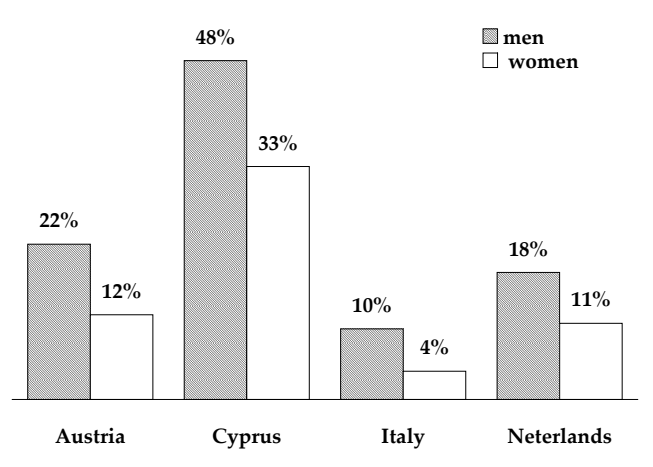

b) Directly held stocks 
Table 4: Descriptive statistics by gender

\begin{tabular}{|c|c|c|c|c|c|c|c|c|c|c|}
\hline & \multicolumn{2}{|c|}{$\mathrm{AU}$} & \multicolumn{2}{|c|}{ CY } & \multicolumn{2}{|c|}{ DE } & \multicolumn{2}{|c|}{ IT } & \multicolumn{2}{|c|}{ NL } \\
\hline & $\begin{array}{c}\text { Males } \\
\mathrm{N}=1,640 \\
(64 \%)\end{array}$ & $\begin{array}{c}\text { Females } \\
\mathrm{N}=916 \\
(36 \%)\end{array}$ & $\begin{array}{l}\text { Males } \\
\mathrm{N}=438 \\
(62 \%)\end{array}$ & $\begin{array}{c}\text { Females } \\
\mathrm{N}=265 \\
(38 \%)\end{array}$ & $\begin{array}{c}\text { Males } \\
\text { N=4,858 } \\
(59 \%)\end{array}$ & $\begin{array}{c}\text { Females } \\
\mathrm{N}=3,335 \\
(41 \%)\end{array}$ & $\begin{array}{c}\text { Males } \\
\mathrm{N}=4,885 \\
(61 \%)\end{array}$ & $\begin{array}{c}\text { Females } \\
\mathrm{N}=3,123 \\
(39 \%)\end{array}$ & $\begin{array}{c}\text { Males } \\
\mathrm{N}=1,117 \\
(78 \%)\end{array}$ & $\begin{array}{c}\text { Females } \\
\mathrm{N}=304 \\
(22 \%)\end{array}$ \\
\hline Risky Assets & $\begin{array}{c}0.28 \\
(0.45)\end{array}$ & $\begin{array}{c}0.18 \\
(0.38)\end{array}$ & $\begin{array}{c}0.48 \\
(0.50)\end{array}$ & $\begin{array}{c}0.33 \\
(0.47)\end{array}$ & $\begin{array}{c}0.36 \\
(0.48)\end{array}$ & $\begin{array}{c}0.27 \\
(0.44)\end{array}$ & $\begin{array}{c}0.18 \\
(0.38)\end{array}$ & $\begin{array}{c}0.09 \\
(0.29)\end{array}$ & $\begin{array}{c}0.30 \\
(0.46)\end{array}$ & $\begin{array}{c}0.25 \\
(0.43)\end{array}$ \\
\hline Stocks & $\begin{array}{c}0.22 \\
(0.41)\end{array}$ & $\begin{array}{c}0.12 \\
(0.33)\end{array}$ & $\begin{array}{c}0.48 \\
(0.50)\end{array}$ & $\begin{array}{c}0.33 \\
(0.47)\end{array}$ & - & $\begin{array}{l}- \\
-\end{array}$ & $\begin{array}{c}0.10 \\
(0.30)\end{array}$ & $\begin{array}{c}0.04 \\
(0.19)\end{array}$ & $\begin{array}{c}0.18 \\
(0.39)\end{array}$ & $\begin{array}{c}0.11 \\
(0.30)\end{array}$ \\
\hline Savings & $\begin{array}{c}0.97 \\
(0.17)\end{array}$ & $\begin{array}{c}0.93 \\
(0.25)\end{array}$ & $\begin{array}{c}0.61 \\
(0.49)\end{array}$ & $\begin{array}{c}0.53 \\
(0.50)\end{array}$ & $\begin{array}{c}0.72 \\
(0.44)\end{array}$ & $\begin{array}{c}0.67 \\
(0.45)\end{array}$ & $\begin{array}{c}0.80 \\
(0.40)\end{array}$ & $\begin{array}{c}0.72 \\
(0.45)\end{array}$ & $\begin{array}{c}0.87 \\
(0.33)\end{array}$ & $\begin{array}{c}0.80 \\
(0.40)\end{array}$ \\
\hline Real Property & $\begin{array}{l}- \\
-\end{array}$ & $\begin{array}{l}- \\
-\end{array}$ & $\begin{array}{c}0.69 \\
(0.46)\end{array}$ & $\begin{array}{c}0.58 \\
(0.37)\end{array}$ & $\begin{array}{c}0.41 \\
(0.49)\end{array}$ & $\begin{array}{c}0.54 \\
(0.50)\end{array}$ & $\begin{array}{c}0.72 \\
(0.45)\end{array}$ & $\begin{array}{c}0.67 \\
(0.47)\end{array}$ & $\begin{array}{c}0.73 \\
(0.45)\end{array}$ & $\begin{array}{c}0.53 \\
(0.50)\end{array}$ \\
\hline Income & $\begin{array}{c}33,966 \\
(13,680)\end{array}$ & $\begin{array}{c}5,256 \\
(13,023)\end{array}$ & $\begin{array}{c}23,541 \\
(93,867)\end{array}$ & $\begin{array}{c}14,277 \\
(17,936)\end{array}$ & $\begin{array}{c}37,860 \\
(36,326)\end{array}$ & $\begin{array}{c}4,042 \\
(18,573)\end{array}$ & $\begin{array}{c}27,359 \\
(28,191)\end{array}$ & $\begin{array}{c}9,845 \\
(15,856)\end{array}$ & $\begin{array}{c}38,574 \\
(20,477)\end{array}$ & $\begin{array}{c}30,278 \\
(18,418)\end{array}$ \\
\hline Financial Wealth & $\begin{array}{c}56,865 \\
(120,098)\end{array}$ & $\begin{array}{c}29,575 \\
(53,171)\end{array}$ & $\begin{array}{c}34,639 \\
(25,0587)\end{array}$ & $\begin{array}{c}6,897 \\
(13,286)\end{array}$ & $\begin{array}{c}24,211 \\
(101,210)\end{array}$ & $\begin{array}{c}0,704 \\
(37,423)\end{array}$ & $\begin{array}{c}25,404 \\
(72,627)\end{array}$ & $\begin{array}{c}5,728 \\
(55,711)\end{array}$ & $\begin{array}{c}32,323 \\
(69,393)\end{array}$ & $\begin{array}{c}23,581 \\
(42,688)\end{array}$ \\
\hline Age & $\begin{array}{c}52.56 \\
(14.11)\end{array}$ & $\begin{array}{c}50.90 \\
(15.58)\end{array}$ & $\begin{array}{c}50.90 \\
(13.93)\end{array}$ & $\begin{array}{c}45.70 \\
(14.85)\end{array}$ & $\begin{array}{c}52.03 \\
(14.98)\end{array}$ & $\begin{array}{c}9.97 \\
(18.23)\end{array}$ & $\begin{array}{c}56.14 \\
(14.81)\end{array}$ & $\begin{array}{c}57.89 \\
(17.12)\end{array}$ & $\begin{array}{c}52.92 \\
(14.35)\end{array}$ & $\begin{array}{c}47.72 \\
(14.69)\end{array}$ \\
\hline Employed & $\begin{array}{c}0.55 \\
(0.50)\end{array}$ & $\begin{array}{c}0.37 \\
(0.48)\end{array}$ & $\begin{array}{c}0.74 \\
(0.43)\end{array}$ & $\begin{array}{c}0.69 \\
(0.46)\end{array}$ & $\begin{array}{c}0.54 \\
(0.50)\end{array}$ & $\begin{array}{c}0.45 \\
(0.50)\end{array}$ & $\begin{array}{c}0.52 \\
(0.50)\end{array}$ & $\begin{array}{c}0.31 \\
(0.46)\end{array}$ & $\begin{array}{c}0.64 \\
(0.48)\end{array}$ & $\begin{array}{c}0.68 \\
(0.47)\end{array}$ \\
\hline Self-Employed & $\begin{array}{c}0.08 \\
(0.27)\end{array}$ & $\begin{array}{c}0.05 \\
(0.23)\end{array}$ & $\begin{array}{c}0.24 \\
(0.43)\end{array}$ & $\begin{array}{c}0.19 \\
(0.39)\end{array}$ & $\begin{array}{c}0.08 \\
(0.27)\end{array}$ & $\begin{array}{c}0.04 \\
(0.20)\end{array}$ & $\begin{array}{c}0.14 \\
(0.35)\end{array}$ & $\begin{array}{c}0.05 \\
(0.22)\end{array}$ & $\begin{array}{c}0.03 \\
(0.18)\end{array}$ & $\begin{array}{c}0.03 \\
(0.17)\end{array}$ \\
\hline Retired & $\begin{array}{c}0.39 \\
(0.49)\end{array}$ & $\begin{array}{c}0.30 \\
(0.46)\end{array}$ & $\begin{array}{c}0.22 \\
(0.41)\end{array}$ & $\begin{array}{c}0.07 \\
(0.26)\end{array}$ & $\begin{array}{c}0.27 \\
(0.44)\end{array}$ & $\begin{array}{c}0.28 \\
(0.45)\end{array}$ & $\begin{array}{c}0.45 \\
(0.50)\end{array}$ & $\begin{array}{c}0.44 \\
(0.50)\end{array}$ & $\begin{array}{c}0.27 \\
(0.44)\end{array}$ & $\begin{array}{c}0.11 \\
(0.31)\end{array}$ \\
\hline University & $\begin{array}{c}0.39 \\
(0.49)\end{array}$ & $\begin{array}{c}0.43 \\
(0.50)\end{array}$ & $\begin{array}{c}0.33 \\
(0.48)\end{array}$ & $\begin{array}{c}0.34 \\
(0.48)\end{array}$ & $\begin{array}{c}0.24 \\
(0.43)\end{array}$ & $\begin{array}{c}0.16 \\
(0.38)\end{array}$ & $\begin{array}{c}0.10 \\
(0.29)\end{array}$ & $\begin{array}{c}0.07 \\
(0.26)\end{array}$ & $\begin{array}{c}0.41 \\
(0.49)\end{array}$ & $\begin{array}{c}0.51 \\
(0.50)\end{array}$ \\
\hline No of children & $\begin{array}{c}0.50 \\
(0.92)\end{array}$ & $\begin{array}{c}0.40 \\
(0.84)\end{array}$ & $\begin{array}{c}0.90 \\
(1.15)\end{array}$ & $\begin{array}{c}0.89 \\
(1.14)\end{array}$ & $\begin{array}{c}0.44 \\
(0.86)\end{array}$ & $\begin{array}{c}0.42 \\
(0.80)\end{array}$ & $\begin{array}{c}0.41 \\
(0.77)\end{array}$ & $\begin{array}{c}0.32 \\
(0.70)\end{array}$ & $\begin{array}{c}0.65 \\
(1.05)\end{array}$ & $\begin{array}{c}0.31 \\
(0.77)\end{array}$ \\
\hline Single & $\begin{array}{c}0.21 \\
(0.41)\end{array}$ & $\begin{array}{c}0.69 \\
(0.46)\end{array}$ & $\begin{array}{c}0.06 \\
(0.23)\end{array}$ & $\begin{array}{c}0.20 \\
(0.40)\end{array}$ & $\begin{array}{c}0.35 \\
(0.48)\end{array}$ & $\begin{array}{c}0.67 \\
(0.46)\end{array}$ & $\begin{array}{c}0.19 \\
(0.40)\end{array}$ & $\begin{array}{c}0.62 \\
(0.49)\end{array}$ & $\begin{array}{c}0.44 \\
(0.50)\end{array}$ & $\begin{array}{c}0.89 \\
(0.32)\end{array}$ \\
\hline
\end{tabular}

The table reports sample means and standard deviations (in parentheses) of the variables.

Figure 2: Share of financial wealth invested in risky assets (conditional on ownership)

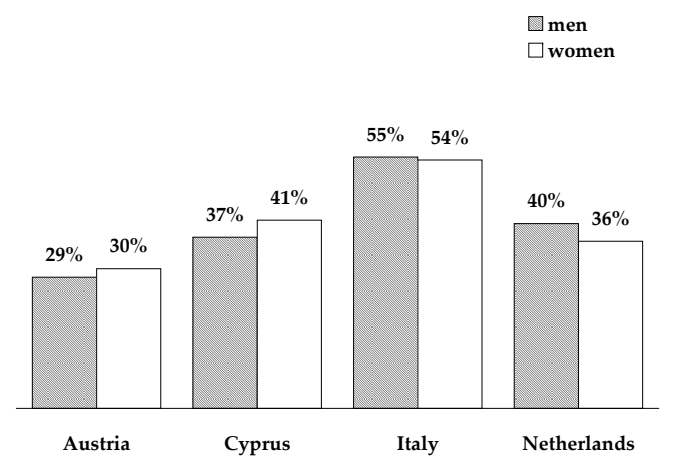

a) Total risky financial assets

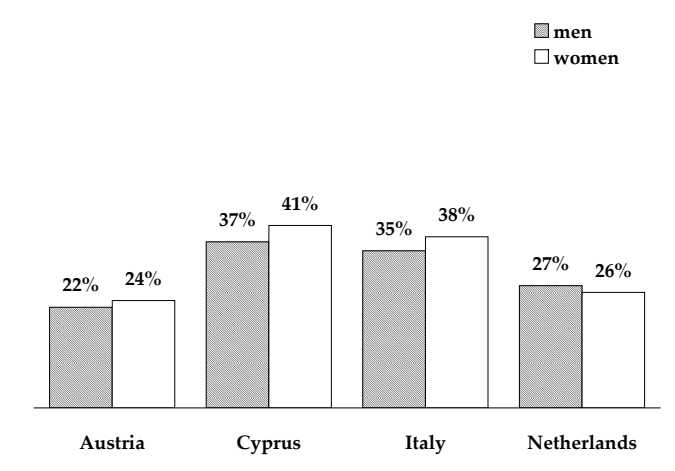

b) Directly held stocks 


\section{Table 5: Probability of investing in risky financial assets}

This table summarizes the results of estimation of model (1) by means of a probit regression. The dependent variable is a binary variable equal to 1 if risky financial assets are held and 0 otherwise. The upper part of the table reports marginal effects of the explanatory variables on the probability of holding risky financial assets. The effects are predicted at mean values of the explanatory variables. ${ }^{*}$,** and ${ }^{* * *}$ correspond to $10 \%, 5 \%$ and $1 \%$ significance levels respectively. $\operatorname{Pr}(Y=1 \mid$ Male $=0)$ denotes the predicted probability that a female owns risky assets. The predicted value is calculated at mean values of the explanatory variables.

\begin{tabular}{|c|c|c|c|c|c|}
\hline & Austria & Cyprus & Germany & Italy & Netherlands \\
\hline Male & $\begin{array}{l}0.069^{* * *} \\
(0.019)\end{array}$ & $\begin{array}{l}0.074^{*} \\
(0.044)\end{array}$ & $\begin{array}{l}0.004 \\
(0.012)\end{array}$ & $\begin{array}{l}0.018^{* * *} \\
(0.005)\end{array}$ & $\begin{array}{l}0.025 \\
(0.033)\end{array}$ \\
\hline $\ln$ (Income) & $\begin{array}{l}0.138^{* * *} \\
(0.024)\end{array}$ & $\begin{array}{l}0.018^{*} \\
(0.009)\end{array}$ & $\begin{array}{l}0.172^{* * *} \\
(0.012)\end{array}$ & $\begin{array}{l}0.029 * * * \\
(0.005)\end{array}$ & $\begin{array}{l}0.034 \\
(0.021)\end{array}$ \\
\hline 2nd wealth quartile & $\begin{array}{l}0.199^{* * * *} \\
(0.040)\end{array}$ & $\begin{array}{l}0.400^{* * *} \\
(0.061)\end{array}$ & $\begin{array}{l}0.172^{* * *} \\
(0.019)\end{array}$ & $\begin{array}{l}0.115^{* * *} \\
(0.034)\end{array}$ & $\begin{array}{l}0.065 \\
(0.041)\end{array}$ \\
\hline 3rd wealth quartile & $\begin{array}{l}0.386^{* * *} \\
(0.041)\end{array}$ & $\begin{array}{l}0.447^{* * *} \\
(0.060)\end{array}$ & $\begin{array}{l}0.322^{* * *} \\
(0.018)\end{array}$ & $\begin{array}{l}0.353^{* * *} \\
(0.050)\end{array}$ & $\begin{array}{l}0.256^{* * *} \\
(0.043)\end{array}$ \\
\hline 4th wealth quartile & $\begin{array}{l}0.647^{* * *} \\
(0.035)\end{array}$ & $\begin{array}{l}0.580^{* * * *} \\
(0.052)\end{array}$ & $\begin{array}{l}0.513^{* * *} \\
(0.017)\end{array}$ & $\begin{array}{l}0.603^{* * * *} \\
(0.047)\end{array}$ & $\begin{array}{l}0.508^{* * *} \\
(0.041)\end{array}$ \\
\hline Real Property & $\begin{array}{l}- \\
-\end{array}$ & $\begin{array}{l}0.048 \\
(0.046)\end{array}$ & $\begin{array}{l}-0.067^{* * * *} \\
(0.012)\end{array}$ & $\begin{array}{l}0.012^{* *} \\
(0.005)\end{array}$ & $\begin{array}{l}0.044 \\
(0.028)\end{array}$ \\
\hline Employed & $\begin{array}{l}-0.061^{* *} \\
(0.027)\end{array}$ & $\begin{array}{l}0.108 \\
(0.086)\end{array}$ & $\begin{array}{l}-0.012 \\
(0.017)\end{array}$ & $\begin{array}{l}0.014 \\
(0.009)\end{array}$ & $\begin{array}{l}-0.121^{* * *} \\
(0.046)\end{array}$ \\
\hline Self-Employed & $\begin{array}{l}0.002 \\
(0.031)\end{array}$ & $\begin{array}{l}0.025 \\
(0.051)\end{array}$ & $\begin{array}{l}-0.084^{* * * *} \\
(0.018)\end{array}$ & $\begin{array}{l}-0.008 \\
(0.005)\end{array}$ & $\begin{array}{l}0.072 \\
(0.069)\end{array}$ \\
\hline Retired & $\begin{array}{l}-0.020 \\
(0.034)\end{array}$ & $\begin{array}{l}0.141 \\
(0.121)\end{array}$ & $\begin{array}{l}-0.044^{*} \\
(0.024)\end{array}$ & $\begin{array}{l}0.006 \\
(0.010)\end{array}$ & $\begin{array}{l}-0.102^{* *} \\
(0.047)\end{array}$ \\
\hline University & $\begin{array}{l}0.078^{* * *} \\
(0.017)\end{array}$ & $\begin{array}{l}0.178^{* * *} \\
(0.045)\end{array}$ & $\begin{array}{l}0.089^{* * *} \\
(0.014)\end{array}$ & $\begin{array}{l}0.036^{* * *} \\
(0.010)\end{array}$ & $\begin{array}{l}0.104^{* * *} \\
(0.026)\end{array}$ \\
\hline Age 30-39 & $\begin{array}{l}-0.053 \\
(0.032)\end{array}$ & $\begin{array}{l}0.134 \\
(0.087)\end{array}$ & $\begin{array}{l}-0.043^{* *} \\
(0.021)\end{array}$ & $\begin{array}{l}0.061^{*} \\
(0.033)\end{array}$ & $\begin{array}{l}0.027 \\
(0.067)\end{array}$ \\
\hline Age $40-49$ & $\begin{array}{l}-0.122^{* * *} \\
(0.027)\end{array}$ & $\begin{array}{l}0.125 \\
(0.083)\end{array}$ & $\begin{array}{l}-0.121^{* * *} \\
(0.019)\end{array}$ & $\begin{array}{l}0.052^{*} \\
(0.029)\end{array}$ & $\begin{array}{l}-0.006 \\
(0.066)\end{array}$ \\
\hline Age 50-59 & $\begin{array}{l}-0.165^{* * *} \\
(0.020)\end{array}$ & $\begin{array}{l}0.173^{* *} \\
(0.087)\end{array}$ & $\begin{array}{l}-0.152^{* * *} \\
(0.018)\end{array}$ & $\begin{array}{l}0.039 \\
(0.026)\end{array}$ & $\begin{array}{l}-0.030 \\
(0.063)\end{array}$ \\
\hline Age 60-69 & $\begin{array}{l}-0.145^{* * *} \\
(0.029)\end{array}$ & $\begin{array}{l}0.105 \\
(0.114)\end{array}$ & $\begin{array}{l}-0.182^{* * *} \\
(0.021)\end{array}$ & $\begin{array}{l}0.041 \\
(0.028)\end{array}$ & $\begin{array}{l}-0.047 \\
(0.070)\end{array}$ \\
\hline Age $\geq 70$ & $\begin{array}{l}-0.171^{* * *} \\
(0.018)\end{array}$ & $\begin{array}{l}-0.120 \\
(0.120)\end{array}$ & $\begin{array}{l}-0.246^{* * *} \\
(0.017)\end{array}$ & $\begin{array}{l}0.016 \\
(0.023)\end{array}$ & $\begin{array}{l}0.039 \\
(0.089)\end{array}$ \\
\hline Single & $\begin{array}{l}0.092^{* * *} \\
(0.025)\end{array}$ & $\begin{array}{l}-0.173^{* *} \\
(0.068)\end{array}$ & $\begin{array}{l}0.012 \\
(0.014)\end{array}$ & $\begin{array}{l}0.006 \\
(0.005)\end{array}$ & $\begin{array}{l}-0.008 \\
(0.028)\end{array}$ \\
\hline No of children & $\begin{array}{l}-0.005 \\
(0.010)\end{array}$ & $\begin{array}{l}0.024 \\
(0.022)\end{array}$ & $\begin{array}{l}-0.028^{* * * *} \\
(0.008)\end{array}$ & $\begin{array}{l}0.002 \\
(0.003)\end{array}$ & $\begin{array}{l}0.022 \\
(0.014)\end{array}$ \\
\hline $\operatorname{Pr}(Y=1 \mid$ Male $=0)$ & 0.160 & 0.375 & 0.272 & 0.043 & 0.244 \\
\hline $\operatorname{Pr}\left(\chi^{2}\right)$ & 0.000 & 0.000 & 0.000 & 0.000 & 0.000 \\
\hline Log-Likelihood & -1020.96 & -367.36 & -3967.04 & -2197.81 & -717.79 \\
\hline Pseudo- $R^{2}$ & 0.278 & 0.232 & 0.234 & 0.342 & 0.169 \\
\hline No of obs. & 2,556 & 703 & 8,193 & 8,008 & 1,421 \\
\hline
\end{tabular}




\section{Table 6: Probability of investing in directly held stocks}

This table summarizes the results of estimation of model (1) by means of a probit regression. The dependent variable is a binary variable equal to 1 if directly held stocks are owned and 0 otherwise. The upper part of the table reports marginal effects of the explanatory variables on the probability of holding stocks. The effects are predicted at mean values of the explanatory variables. *, ** and *** correspond to $10 \%, 5 \%$ and $1 \%$ significance levels respectively. $\operatorname{Pr}(Y=1 \mid$ Male $=0)$ denotes the predicted probability that a female owns stocks. The predicted value is calculated at mean values of the explanatory variables.

\begin{tabular}{|c|c|c|c|c|}
\hline & Austria & Cyprus & Italy & Netherlands \\
\hline Male & $\begin{array}{l}0.048^{* * *} \\
(0.015)\end{array}$ & $\begin{array}{l}0.070^{*} \\
(0.042)\end{array}$ & $\begin{array}{l}0.011^{* * *} \\
(0.003)\end{array}$ & $\begin{array}{l}0.041^{* *} \\
(0.020)\end{array}$ \\
\hline $\ln$ (Income) & $\begin{array}{l}0.094^{* * *} \\
(0.019)\end{array}$ & $\begin{array}{l}0.020^{* *} \\
(0.009)\end{array}$ & $\begin{array}{l}0.017^{* * *} \\
(0.003)\end{array}$ & $\begin{array}{l}0.015 \\
(0.013)\end{array}$ \\
\hline 2nd wealth quartile & $\begin{array}{l}0.135^{* * *} \\
(0.038)\end{array}$ & $\begin{array}{l}0.399^{* * * *} \\
(0.061)\end{array}$ & $\begin{array}{l}0.056^{* *} \\
(0.024)\end{array}$ & $\begin{array}{l}0.091^{* *} \\
(0.036)\end{array}$ \\
\hline 3rd wealth quartile & $\begin{array}{l}0.270^{* * *} \\
(0.041)\end{array}$ & $\begin{array}{l}0.441^{* * *} \\
(0.060)\end{array}$ & $\begin{array}{l}0.164^{* * *} \\
(0.045)\end{array}$ & $\begin{array}{l}0.147^{* * *} \\
(0.041)\end{array}$ \\
\hline 4th wealth quartile & $\begin{array}{l}0.541^{* * *} \\
(0.042)\end{array}$ & $\begin{array}{l}0.576^{* * *} \\
(0.052)\end{array}$ & $\begin{array}{l}0.313^{* * *} \\
(0.059)\end{array}$ & $\begin{array}{l}0.375^{* * *} \\
(0.055)\end{array}$ \\
\hline Real Property & - & $\begin{array}{l}0.043 \\
(0.046)\end{array}$ & $\begin{array}{l}0.004^{*} \\
(0.002)\end{array}$ & $\begin{array}{l}0.032^{* *} \\
(0.016)\end{array}$ \\
\hline Employed & $\begin{array}{l}-0.027 \\
(0.022)\end{array}$ & $\begin{array}{l}0.109 \\
(0.086)\end{array}$ & $\begin{array}{l}0.003 \\
(0.005)\end{array}$ & $\begin{array}{l}-0.115^{* * *} \\
(0.034)\end{array}$ \\
\hline Self-Employed & $\begin{array}{l}0.000 \\
(0.024)\end{array}$ & $\begin{array}{l}0.018 \\
(0.051)\end{array}$ & $\begin{array}{l}-0.003 \\
(0.003)\end{array}$ & $\begin{array}{l}0.032 \\
(0.043)\end{array}$ \\
\hline Retired & $\begin{array}{l}0.014 \\
(0.027)\end{array}$ & $\begin{array}{l}0.132 \\
(0.121)\end{array}$ & $\begin{array}{l}0.001 \\
(0.005)\end{array}$ & $\begin{array}{l}-0.064^{* * *} \\
(0.020)\end{array}$ \\
\hline University & $\begin{array}{l}0.048^{* * * *} \\
(0.014)\end{array}$ & $\begin{array}{l}0.180^{* * *} \\
(0.044)\end{array}$ & $\begin{array}{l}0.017^{* * * *} \\
(0.006)\end{array}$ & $\begin{array}{l}0.045^{* * *} \\
(0.016)\end{array}$ \\
\hline Age $30-39$ & $\begin{array}{l}-0.049^{* *} \\
(0.024)\end{array}$ & $\begin{array}{l}0.135 \\
(0.087)\end{array}$ & $\begin{array}{l}0.050^{*} \\
(0.030)\end{array}$ & $\begin{array}{l}0.013 \\
(0.041)\end{array}$ \\
\hline Age $40-49$ & $\begin{array}{l}-0.088^{* * *} \\
(0.021)\end{array}$ & $\begin{array}{l}0.127 \\
(0.083)\end{array}$ & $\begin{array}{l}0.044^{*} \\
(0.026)\end{array}$ & $\begin{array}{l}0.004 \\
(0.040)\end{array}$ \\
\hline Age 50-59 & $\begin{array}{l}-0.103^{* * *} \\
(0.017)\end{array}$ & $\begin{array}{l}0.169^{*} \\
(0.087)\end{array}$ & $\begin{array}{l}0.034 \\
(0.022)\end{array}$ & $\begin{array}{l}-0.012 \\
(0.036)\end{array}$ \\
\hline Age 60-69 & $\begin{array}{l}-0.106^{* * *} \\
(0.022)\end{array}$ & $\begin{array}{l}0.102 \\
(0.114)\end{array}$ & $\begin{array}{l}0.034 \\
(0.023)\end{array}$ & $\begin{array}{l}-0.025 \\
(0.036)\end{array}$ \\
\hline Age $\geq 70$ & $\begin{array}{l}-0.120^{* * *} \\
(0.013)\end{array}$ & $\begin{array}{l}-0.104 \\
(0.122)\end{array}$ & $\begin{array}{l}0.027 \\
(0.019)\end{array}$ & $\begin{array}{l}-0.003 \\
(0.046)\end{array}$ \\
\hline Single & $\begin{array}{l}0.046^{* *} \\
(0.020)\end{array}$ & $\begin{array}{l}-0.168^{* *} \\
(0.068)\end{array}$ & $\begin{array}{l}0.003 \\
(0.003)\end{array}$ & $\begin{array}{l}-0.011 \\
(0.015)\end{array}$ \\
\hline No of children & $\begin{array}{l}-0.009 \\
(0.008)\end{array}$ & $\begin{array}{l}0.025 \\
(0.022)\end{array}$ & $\begin{array}{l}0.003^{* * *} \\
(0.002)\end{array}$ & $\begin{array}{l}0.013^{*} \\
(0.008)\end{array}$ \\
\hline $\operatorname{Pr}(Y=1 \mid$ Male $=0)$ & 0.106 & 0.372 & 0.015 & 0.077 \\
\hline $\operatorname{Pr}\left(\chi^{2}\right)$ & 0.000 & 0.000 & 0.000 & 0.000 \\
\hline Log-Likelihood & -897.05 & -367.71 & -1506.51 & -497.10 \\
\hline Pseudo- $R^{2}$ & 0.258 & 0.230 & 0.287 & 0.186 \\
\hline No of obs. & 2,556 & 703 & 8,008 & 1,421 \\
\hline
\end{tabular}




\section{Table 7: Conditional portfolio share invested in risky assets}

This table summarizes the results of estimation of model (2) by means of Heckman's two-step procedure. The dependent variable is the portfolio share invested in risky financial assets. The upper part of the table reports the estimated coefficients on the explanatory variables in the main (second stage) equation. The coefficients are predicted at mean values of the explanatory variables. The specification of the first stage selection equation corresponds to the probit regression for the participation decision and includes the following variables: logarithm of income, number of children, dummies for sex, education, employment, family status, age groups, and wealth quartiles. In the present table, we report only the estimates on wealth quartile dummies, which serve as selection equation instruments. ${ }^{*}, * *$ and ${ }^{* * *}$ correspond to $10 \%, 5 \%$ and $1 \%$ significance levels respectively.

\begin{tabular}{|c|c|c|c|c|}
\hline & Austria & Cyprus & Italy & Netherlands \\
\hline Male & $\begin{array}{l}0.001 \\
(0.022)\end{array}$ & $\begin{array}{l}0.042 \\
(0.053)\end{array}$ & $\begin{array}{l}0.027 \\
(0.020)\end{array}$ & $\begin{array}{l}0.058 \\
(0.040)\end{array}$ \\
\hline \multirow[t]{2}{*}{$\ln ($ Income $)$} & 0.022 & $0.020^{*}$ & -0.017 & 0.005 \\
\hline & $(0.030)$ & $(0.012)$ & (0.017) & $(0.027)$ \\
\hline \multirow[t]{2}{*}{$\ln$ (Wealth) } & $0.034^{* *}$ & -0.035 & $0.035^{* * *}$ & $0.048^{* *}$ \\
\hline & $(0.014)$ & $(0.023)$ & (0.012) & $(0.025)$ \\
\hline \multirow[t]{2}{*}{ Real Property } & - & $0.095^{*}$ & -0.003 & $0.106^{* * *}$ \\
\hline & - & $(0.053)$ & $(0.022)$ & $(0.038)$ \\
\hline \multirow[t]{2}{*}{ Employed } & -0.015 & 0.216 & 0.043 & -0.039 \\
\hline & $(0.028)$ & $(0.134)$ & $(0.037)$ & $(0.056)$ \\
\hline \multirow[t]{2}{*}{ Self-Employed } & 0.040 & $0.094^{*}$ & 0.006 & 0.028 \\
\hline & $(0.030)$ & $(0.054)$ & $(0.023)$ & $(0.083)$ \\
\hline \multirow[t]{2}{*}{ Retired } & 0.012 & $0.338^{* *}$ & -0.036 & -0.027 \\
\hline & $(0.037)$ & $(0.166)$ & $(0.038)$ & $(0.067)$ \\
\hline \multirow[t]{2}{*}{ University } & 0.014 & $0.216^{* * *}$ & -0.008 & $0.063^{*}$ \\
\hline & $(0.018)$ & $(0.058)$ & $(0.021)$ & $(0.035)$ \\
\hline \multirow[t]{2}{*}{ Age 30-39 } & 0.026 & $0.289^{* * *}$ & $0.137^{*}$ & 0.048 \\
\hline & $(0.040)$ & $(0.103)$ & $(0.079)$ & $(0.089)$ \\
\hline \multirow[t]{2}{*}{ Age 40-49 } & -0.027 & $0.236^{* *}$ & $0.147^{*}$ & 0.106 \\
\hline & $(0.040)$ & $(0.099)$ & (0.079) & $(0.091)$ \\
\hline \multirow[t]{2}{*}{ Age 50-59 } & -0.069 & $0.248^{* *}$ & $0.154^{* *}$ & 0.078 \\
\hline & $(0.045)$ & $(0.103)$ & $(0.078)$ & $(0.091)$ \\
\hline \multirow[t]{2}{*}{ Age 60-69 } & -0.033 & 0.210 & $0.257^{* * *}$ & 0.078 \\
\hline & $(0.049)$ & $(0.135)$ & $(0.081)$ & $(0.101)$ \\
\hline \multirow[t]{2}{*}{ Age $\geq 70$} & -0.078 & -0.048 & $0.161^{* *}$ & 0.082 \\
\hline & $(0.059)$ & $(0.170)$ & $(0.082)$ & $(0.111)$ \\
\hline \multirow[t]{2}{*}{ Single } & 0.035 & -0.122 & $0.043^{* *}$ & $0.067^{*}$ \\
\hline & $(0.024)$ & $(0.127)$ & $(0.021)$ & $(0.035)$ \\
\hline \multirow[t]{2}{*}{ No of children } & $-0.026^{* *}$ & 0.027 & $0.022^{*}$ & 0.001 \\
\hline & $(0.011)$ & $(0.025)$ & $(0.013)$ & $(0.017)$ \\
\hline \multirow[t]{2}{*}{ Constant } & -0.361 & -0.459 & 0.034 & -0.547 \\
\hline & $(0.390)$ & $(0.433)$ & $(0.260)$ & $(0.451)$ \\
\hline \multicolumn{5}{|c|}{ Selection Equation Instruments } \\
\hline \multirow[t]{2}{*}{ 2nd wealth quartile } & $0.701^{* * *}$ & $1.051^{* * *}$ & $0.879^{* * *}$ & $0.704^{* * *}$ \\
\hline & $(0.132)$ & $(0.171)$ & $(0.227)$ & $(0.154)$ \\
\hline \multirow[t]{2}{*}{ 3rd wealth quartile } & $1.263^{* * *}$ & $1.185^{* * *}$ & $1.804^{* * *}$ & $1.317^{* * *}$ \\
\hline & $(0.130)$ & $(0.171)$ & $(0.220)$ & $(0.150)$ \\
\hline \multirow[t]{2}{*}{ 4th wealth quartile } & $2.073^{* * *}$ & $1.618^{* * *}$ & $2.674^{* * *}$ & $2.063^{* * *}$ \\
\hline & $(0.134)$ & $(0.177)$ & $(0.220)$ & $(0.154)$ \\
\hline \multirow[t]{2}{*}{$\lambda$} & $0.073^{* *}$ & $0.393^{* * *}$ & $0.101^{* * *}$ & $0.151^{* *}$ \\
\hline & $(0.037)$ & $(0.133)$ & $(0.031)$ & $(0.071)$ \\
\hline$\rho$ & 0.366 & 0.909 & 0.378 & 0.507 \\
\hline$\sigma$ & 0.200 & 0.433 & 0.268 & 0.298 \\
\hline No of obs. & 2,556 & 703 & 8,008 & 1,383 \\
\hline No of censored obs. & 1,937 & 407 & 6,832 & 1,000 \\
\hline
\end{tabular}




\section{Table 8: Conditional portfolio share invested in directly held stocks}

This table summarizes the results of estimation of model (2) by means of Heckman's two-step procedure. The dependent variable is the portfolio share invested in directly held stocks. The upper part of the table reports the estimated coefficients on the explanatory variables in the main (second stage) equation. The coefficients are predicted at mean values of the explanatory variables. The specification of the first stage selection equation corresponds to the probit regression for the participation decision and includes the following variables: logarithm of income, number of children, dummies for sex, education, employment, family status, age groups, and wealth quartiles. In the present table, we report only the estimates on wealth quartile dummies, which serve as selection equation instruments. ${ }^{*}, * *$ and ${ }^{* * *}$ correspond to $10 \%, 5 \%$ and $1 \%$ significance levels respectively.

\begin{tabular}{|c|c|c|c|c|}
\hline & Austria & Cyprus & Italy & Netherlands \\
\hline Male & $\begin{array}{l}0.000 \\
(0.020)\end{array}$ & $\begin{array}{l}0.039 \\
(0.053)\end{array}$ & $\begin{array}{l}0.045^{* *} \\
(0.020)\end{array}$ & $\begin{array}{l}0.096^{*} \\
(0.057)\end{array}$ \\
\hline $\ln$ (Income) & $\begin{array}{l}0.026 \\
(0.026)\end{array}$ & $\begin{array}{l}0.024^{* *} \\
(0.012)\end{array}$ & $\begin{array}{l}0.059^{* * *} \\
(0.016)\end{array}$ & $\begin{array}{l}0.000 \\
(0.039)\end{array}$ \\
\hline $\ln$ (Wealth) & $\begin{array}{l}0.013 \\
(0.012)\end{array}$ & $\begin{array}{l}-0.038 \\
(0.023)\end{array}$ & $\begin{array}{l}0.003 \\
(0.012)\end{array}$ & $\begin{array}{l}0.014 \\
(0.026)\end{array}$ \\
\hline Real Property & - & $\begin{array}{l}0.092^{*} \\
(0.053)\end{array}$ & $\begin{array}{l}0.032 \\
(0.021)\end{array}$ & $\begin{array}{l}0.170^{* * *} \\
(0.052)\end{array}$ \\
\hline Employed & $\begin{array}{l}0.028 \\
(0.025)\end{array}$ & $\begin{array}{l}0.215 \\
(0.133)\end{array}$ & $\begin{array}{l}0.011 \\
(0.036)\end{array}$ & $\begin{array}{l}-0.089 \\
(0.075)\end{array}$ \\
\hline Self-Employed & $\begin{array}{l}0.003 \\
(0.027)\end{array}$ & $\begin{array}{l}0.091^{*} \\
(0.054)\end{array}$ & $\begin{array}{l}0.004 \\
(0.023)\end{array}$ & $\begin{array}{l}-0.113 \\
(0.112)\end{array}$ \\
\hline Retired & $\begin{array}{l}0.084^{* *} \\
(0.033)\end{array}$ & $\begin{array}{l}0.333^{* *} \\
(0.166)\end{array}$ & $\begin{array}{l}-0.014 \\
(0.037)\end{array}$ & $\begin{array}{l}-0.038 \\
(0.080)\end{array}$ \\
\hline University & $\begin{array}{l}-0.007 \\
(0.016)\end{array}$ & $\begin{array}{l}0.216^{* * *} \\
(0.057)\end{array}$ & $\begin{array}{l}0.034^{*} \\
(0.020)\end{array}$ & $\begin{array}{l}0.043 \\
(0.042)\end{array}$ \\
\hline Age 30-39 & $\begin{array}{l}-0.009 \\
(0.036)\end{array}$ & $\begin{array}{l}0.285^{* * *} \\
(0.103)\end{array}$ & $\begin{array}{l}0.122 \\
(0.077)\end{array}$ & $\begin{array}{l}-0.099 \\
(0.124)\end{array}$ \\
\hline Age $40-49$ & $\begin{array}{l}-0.028 \\
(0.036)\end{array}$ & $\begin{array}{l}0.231^{* *} \\
(0.098)\end{array}$ & $\begin{array}{l}0.122 \\
(0.077)\end{array}$ & $\begin{array}{l}-0.161 \\
(0.127)\end{array}$ \\
\hline Age 50-59 & $\begin{array}{l}-0.029 \\
(0.040)\end{array}$ & $\begin{array}{l}0.245^{* *} \\
(0.103)\end{array}$ & $\begin{array}{l}0.100 \\
(0.076)\end{array}$ & $\begin{array}{l}-0.159 \\
(0.127)\end{array}$ \\
\hline Age $60-69$ & $\begin{array}{l}-0.031 \\
(0.044)\end{array}$ & $\begin{array}{l}0.202 \\
(0.135)\end{array}$ & $\begin{array}{l}0.155^{* *} \\
(0.079)\end{array}$ & $\begin{array}{l}-0.188 \\
(0.139)\end{array}$ \\
\hline Age $\geq 70$ & $\begin{array}{l}-0.060 \\
(0.053)\end{array}$ & $\begin{array}{l}-0.032 \\
(0.169)\end{array}$ & $\begin{array}{l}0.115 \\
(0.079)\end{array}$ & $\begin{array}{l}-0.141 \\
(0.145)\end{array}$ \\
\hline Single & $\begin{array}{l}0.024 \\
(0.022)\end{array}$ & $\begin{array}{l}-0.115 \\
(0.127)\end{array}$ & $\begin{array}{l}0.014 \\
(0.020)\end{array}$ & $\begin{array}{l}0.042 \\
(0.045)\end{array}$ \\
\hline No of children & $\begin{array}{l}-0.012 \\
(0.010)\end{array}$ & $\begin{array}{l}0.029 \\
(0.025)\end{array}$ & $\begin{array}{l}0.031^{* *} \\
(0.012)\end{array}$ & $\begin{array}{l}0.003 \\
(0.021)\end{array}$ \\
\hline Constant & $\begin{array}{l}-0.285 \\
(0.348)\end{array}$ & $\begin{array}{l}-0.462 \\
(0.432)\end{array}$ & $\begin{array}{l}-0.793^{* * *} \\
(0.253)\end{array}$ & $\begin{array}{l}-0.136 \\
(0.576)\end{array}$ \\
\hline \multicolumn{5}{|c|}{ Selection Equation Instruments } \\
\hline 2nd wealth quartile & $\begin{array}{l}0.701^{* * *} \\
(0.132)\end{array}$ & $\begin{array}{l}1.051^{* * *} \\
(0.171)\end{array}$ & $\begin{array}{l}0.879^{* * *} \\
(0.227)\end{array}$ & $\begin{array}{l}0.625^{* * *} \\
(0.192)\end{array}$ \\
\hline 3rd wealth quartile & $\begin{array}{l}1.263^{* * *} \\
(0.130)\end{array}$ & $\begin{array}{l}1.185^{* * *} \\
(0.171)\end{array}$ & $\begin{array}{l}1.804^{* * *} \\
(0.220)\end{array}$ & $\begin{array}{l}0.888^{* * *} \\
(0.187)\end{array}$ \\
\hline 4th wealth quartile & $\begin{array}{l}2.073^{* * * *} \\
(0.134)\end{array}$ & $\begin{array}{l}1.618^{* * * *} \\
(0.177)\end{array}$ & $\begin{array}{l}2.674^{* * * *} \\
(0.220)\end{array}$ & $\begin{array}{l}1.743^{* * * *} \\
(0.186)\end{array}$ \\
\hline$\lambda$ & $\begin{array}{l}0.024 \\
(0.033)\end{array}$ & $\begin{array}{l}0.390 * * * \\
(0.133)\end{array}$ & $\begin{array}{l}0.116^{* * *} \\
(0.030)\end{array}$ & $\begin{array}{l}0.160^{* *} \\
(0.080)\end{array}$ \\
\hline$\rho$ & 0.140 & 0.906 & 0.438 & 0.576 \\
\hline$\sigma$ & 0.174 & 0.431 & 0.265 & 0.278 \\
\hline No of obs. & 2,556 & 703 & 8,008 & 1,383 \\
\hline No of censored obs. & 1,937 & 407 & 6,832 & 1,174 \\
\hline
\end{tabular}




\section{Table 9: Survey questions about attitude towards financial risks}

\begin{tabular}{|c|c|}
\hline Country & Survey question \\
\hline Austria & $\begin{array}{l}\text { "For savings I prefer secure investment instruments and avoid risk" } \\
\text { 1=completely applicable; } \\
2=\text { rather applicable; } \\
3=\text { rather not applicable; } \\
4=\text { completely inapplicable. }\end{array}$ \\
\hline Cyprus & $\begin{array}{l}\text { "Which of the statements comes closest to the amount of financial risk that you are willing to take when you save or make } \\
\text { investments?" } \\
1=\text { not willing to take any financial risks; } \\
2=\text { take average financial risks expecting to earn average returns; } \\
3=\text { take above average financial risks expecting to earn above average returns; } \\
4=\text { take substantial financial risks expecting to earn substantial returns. }\end{array}$ \\
\hline Germany & $\begin{array}{l}\text { How would you rate your willingness to take risks in financial matters on the scale from } 0 \text { "risk averse" to } 10 \text { "fully prepared } \\
\text { to take risks" }\end{array}$ \\
\hline Italy & $\begin{array}{l}\text { "Which of the statements on this page comes closest to the amount of financial risk that you are willing to take when you save } \\
\text { or make investments?" } \\
1=\text { low returns, without any risk of losing your capital; } \\
2=\text { a reasonable return, with a good degree of security for your invested capital; } \\
3=\text { a good return, with reasonable security for your invested capital; } \\
4=\text { very high returns, regardless of a high risk of losing part of your capital. }\end{array}$ \\
\hline Netherlands & $\begin{array}{l}\text { Please indicate on a scale from } 1 \text { to } 7 \text { to what extent you agree with the "I am prepared to take the risk to lose money, when } \\
\text { there is also a chance to gain money", where } 1 \text { indicates 'totally disagree' and } 7 \text { indicates 'totally agree'. }\end{array}$ \\
\hline
\end{tabular}

\section{Table 10: Construction of the variables capturing willingness to take financial risks}

\begin{tabular}{|c|c|c|c|}
\hline Country & $\begin{array}{l}\text { Selected } \\
\text { alternative }\end{array}$ & $\begin{array}{c}\text { Generated } \\
\text { variable }\end{array}$ & Description \\
\hline $\begin{array}{l}\text { Austria, } \\
\text { Cyprus and } \\
\text { Italy }\end{array}$ & $\begin{array}{l}1 \\
2 \\
3 \\
4\end{array}$ & $\begin{array}{l}\text { RiskTolerance1 } \\
\text { RiskTolerance2 } \\
\text { RiskTolerance3 } \\
\text { RiskTolerance4 }\end{array}$ & $\begin{array}{l}\text { equal to } 1 \text { if alternative " } 1 \text { " is selected and } 0 \text { otherwise } \\
\text { equal to } 1 \text { if alternative " } 2 \text { " is selected and } 0 \text { otherwise } \\
\text { equal to } 1 \text { if alternative " } 3 \text { " is selected and } 0 \text { otherwise } \\
\text { equal to } 1 \text { if alternative " } 4 \text { " is selected and } 0 \text { otherwise }\end{array}$ \\
\hline Germany & $\begin{array}{l}0 \\
1 \text { to } 3 \\
4 \text { to } 6 \\
7 \text { to } 10\end{array}$ & $\begin{array}{l}\text { RiskTolerance1 } \\
\text { RiskTolerance2 } \\
\text { RiskTolerance3 } \\
\text { RiskTolerance4 }\end{array}$ & $\begin{array}{l}\text { equal to } 1 \text { if alternative " } 0 \text { " is selected and } 0 \text { otherwise } \\
\text { equal to } 1 \text { if alternatives " } 1 \text { " or " } 3 \text { " are selected and } 0 \text { otherwise } \\
\text { equal to } 1 \text { if an alternative from " } 4 \text { " to " } 6 \text { " is selected and } 0 \text { otherwise } \\
\text { equal to } 1 \text { if an alternative from " } 7 \text { " to " } 10 \text { " is selected and } 0 \text { otherwise }\end{array}$ \\
\hline Netherlands & $\begin{array}{l}1 \\
2 \text { or } 3 \\
4 \text { or } 5 \\
6 \text { or } 7\end{array}$ & $\begin{array}{l}\text { RiskTolerance1 } \\
\text { RiskTolerance2 } \\
\text { RiskTolerance3 } \\
\text { RiskTolerance4 }\end{array}$ & $\begin{array}{l}\text { equal to } 1 \text { if alternative " } 0 \text { " is selected and } 0 \text { otherwise } \\
\text { equal to } 1 \text { if alternative " } 2 \text { " or " } 3 \text { " is selected and } 0 \text { otherwise } \\
\text { equal to } 1 \text { if alternative " } 4 \text { " or " } 5 \text { " is selected and } 0 \text { otherwise } \\
\text { equal to } 1 \text { if alternative " } 6 \text { " or " } 7 \text { " are selected and } 0 \text { otherwise }\end{array}$ \\
\hline
\end{tabular}


Figure 3: Distribution of individuals by stated willingness to take financial risks
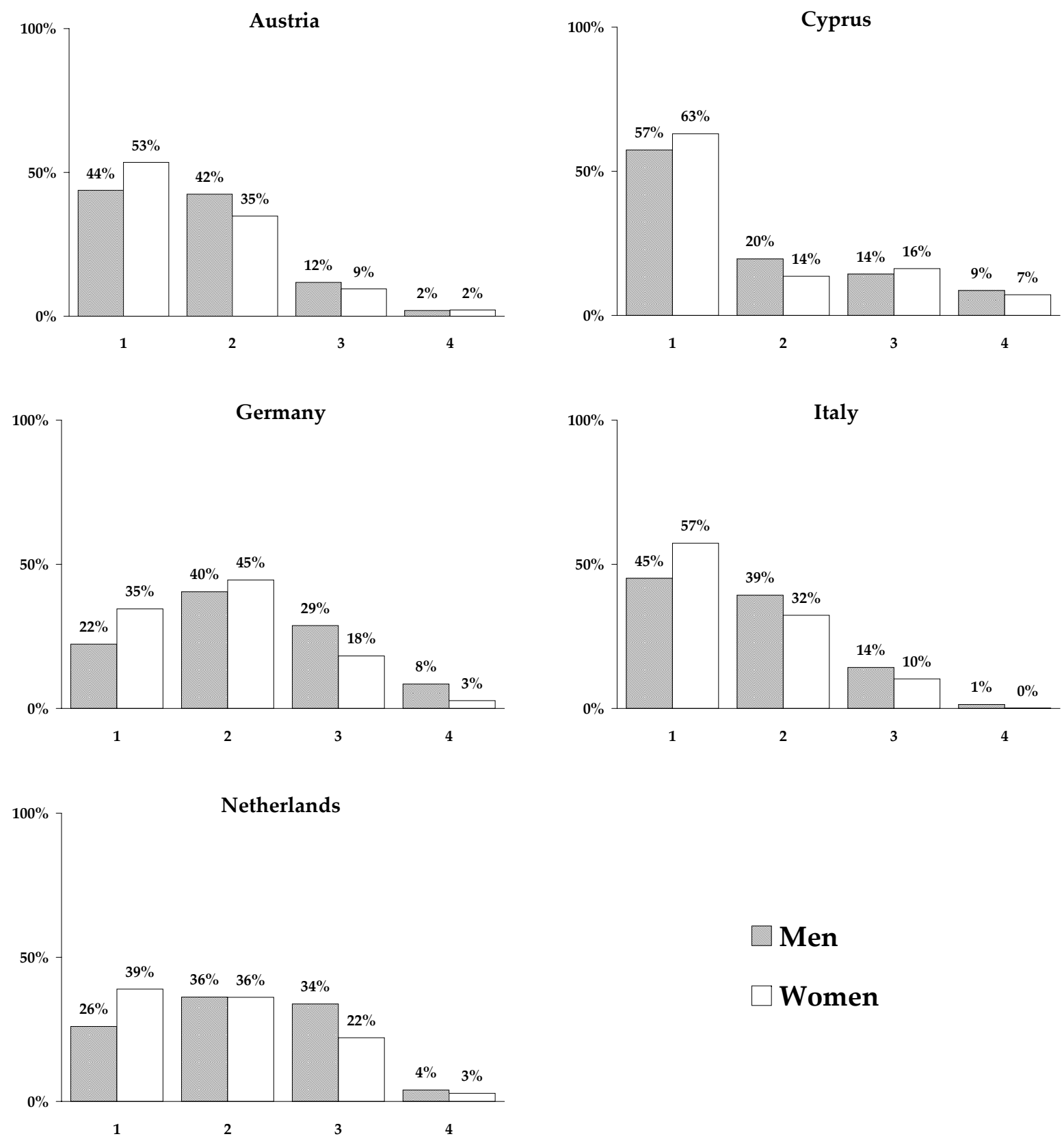

Men

$\square$ Women

Note: Each histogram shows for a given country the distribution of males and females by self-assessed willingness to take financial risks. The strength of the willingness is measured on an ordinal scale where " 1 " correspond to the lowest risk tolerance and " 4 " to the highest risk tolerance. 


\section{Table 11: Probability of investing in risky assets conditional on risk tolerance}

This table summarizes the results of estimation of model (3) by means of a probit regression. The dependent variable is a binary variable equal to 1 if risky financial assets are held and 0 otherwise. The upper part of the table reports marginal effects of the explanatory variables on the probability of holding risky financial assets. The effects are predicted at mean values of the explanatory variables. ${ }^{*}, * *$ and ${ }^{* * *}$ correspond to $10 \%, 5 \%$ and $1 \%$ significance levels respectively. RiskTolerance 1 is a dummy variable indicating the lowest level of risk tolerance; this is the base category and is excluded from the regression equation. $\operatorname{Pr}(Y=1 \mid$ RiskTolerance $1=1$, Male $=0)$ denotes the predicted probability that a female with the lowest willingness to take financial risks owns risky assets. The predicted probability is calculated at mean values of the explanatory variables.

\begin{tabular}{|c|c|c|c|c|c|}
\hline & Austria & Cyprus & Germany & Italy & Netherlands \\
\hline Male & $\begin{array}{l}0.047^{* *} \\
(0.019)\end{array}$ & $\begin{array}{l}0.067 \\
(0.045)\end{array}$ & $\begin{array}{l}-0.027^{* *} \\
(0.012)\end{array}$ & $\begin{array}{l}0.083^{* * *} \\
(0.024)\end{array}$ & $\begin{array}{l}-0.022 \\
(0.043)\end{array}$ \\
\hline RiskTolerance2 & $\begin{array}{l}0.116^{* * *} \\
(0.018)\end{array}$ & $\begin{array}{l}0.138^{* *} \\
(0.059)\end{array}$ & $\begin{array}{l}0.126^{* * *} \\
(0.016)\end{array}$ & $\begin{array}{l}0.236^{* * *} \\
(0.022)\end{array}$ & $\begin{array}{l}0.155^{* * *} \\
(0.047)\end{array}$ \\
\hline RiskTolerance3 & $\begin{array}{l}0.410^{* * *} \\
(0.039)\end{array}$ & $\begin{array}{l}0.078 \\
(0.062)\end{array}$ & $\begin{array}{l}0.232^{* * *} \\
(0.019)\end{array}$ & $\begin{array}{l}0.296^{* * * *} \\
(0.030)\end{array}$ & $\begin{array}{l}0.351^{* * *} \\
(0.048)\end{array}$ \\
\hline RiskTolerance4 & $\begin{array}{l}0.272^{* * * *} \\
(0.079)\end{array}$ & $\begin{array}{l}0.100 \\
(0.077)\end{array}$ & $\begin{array}{l}0.383^{* * * *} \\
(0.027)\end{array}$ & $\begin{array}{l}0.534^{* * *} \\
(0.051)\end{array}$ & $\begin{array}{l}0.430^{* * *} \\
(0.082)\end{array}$ \\
\hline $\ln ($ Income $)$ & $\begin{array}{l}0.124^{* * *} \\
(0.023)\end{array}$ & $\begin{array}{l}0.020^{* *} \\
(0.010)\end{array}$ & $\begin{array}{l}0.168^{* * *} \\
(0.012)\end{array}$ & $\begin{array}{l}0.108^{* * *} \\
(0.021)\end{array}$ & $\begin{array}{l}0.084^{* *} \\
(0.038)\end{array}$ \\
\hline 2nd wealth quartile & $\begin{array}{l}0.242^{* * *} \\
(0.044)\end{array}$ & $\begin{array}{l}0.396^{* * *} \\
(0.062)\end{array}$ & $\begin{array}{l}0.181^{* * *} \\
(0.020)\end{array}$ & $\begin{array}{l}0.283^{* *} \\
(0.135)\end{array}$ & $\begin{array}{l}0.106^{*} \\
(0.059)\end{array}$ \\
\hline 3rd wealth quartile & $\begin{array}{l}0.437^{* * * *} \\
(0.043)\end{array}$ & $\begin{array}{l}0.443^{* * * *} \\
(0.061)\end{array}$ & $\begin{array}{l}0.309^{* * * *} \\
(0.018)\end{array}$ & $\begin{array}{l}0.454^{* * * *} \\
(0.117)\end{array}$ & $\begin{array}{l}0.291^{* * *} \\
(0.057)\end{array}$ \\
\hline 4th wealth quartile & $\begin{array}{l}0.666^{* * *} \\
(0.037)\end{array}$ & $\begin{array}{l}0.556^{* * *} \\
(0.054)\end{array}$ & $\begin{array}{l}0.491^{* * *} \\
(0.018)\end{array}$ & $\begin{array}{l}0.551^{* * *} \\
(0.091)\end{array}$ & $\begin{array}{l}0.553^{* * *} \\
(0.049)\end{array}$ \\
\hline Real Property & - & $\begin{array}{l}0.049 \\
(0.046)\end{array}$ & $\begin{array}{l}-0.065^{* * * *} \\
(0.012)\end{array}$ & $\begin{array}{l}0.030 \\
(0.027)\end{array}$ & $\begin{array}{l}0.011 \\
(0.037)\end{array}$ \\
\hline Employed & $\begin{array}{l}-0.066^{* *} \\
(0.026)\end{array}$ & $\begin{array}{l}0.100 \\
(0.088)\end{array}$ & $\begin{array}{l}-0.021 \\
(0.018)\end{array}$ & $\begin{array}{l}0.033 \\
(0.046)\end{array}$ & $\begin{array}{l}-0.171^{* * *} \\
(0.060)\end{array}$ \\
\hline Self-Employed & $\begin{array}{l}-0.026 \\
(0.027)\end{array}$ & $\begin{array}{l}0.022 \\
(0.052)\end{array}$ & $\begin{array}{l}-0.094^{* * *} \\
(0.018)\end{array}$ & $\begin{array}{l}-0.020 \\
(0.033)\end{array}$ & $\begin{array}{l}0.020 \\
(0.098)\end{array}$ \\
\hline Retired & $\begin{array}{l}-0.020 \\
(0.031)\end{array}$ & $\begin{array}{l}0.145 \\
(0.122)\end{array}$ & $\begin{array}{l}-0.056^{* *} \\
(0.025)\end{array}$ & $\begin{array}{l}-0.023 \\
(0.049)\end{array}$ & $\begin{array}{l}-0.085 \\
(0.061)\end{array}$ \\
\hline University & $\begin{array}{l}0.076^{* * *} \\
(0.017)\end{array}$ & $\begin{array}{l}0.176^{* * *} \\
(0.045)\end{array}$ & $\begin{array}{l}0.077^{* * *} \\
(0.014)\end{array}$ & $\begin{array}{l}0.140^{* * * *} \\
(0.032)\end{array}$ & $\begin{array}{l}0.107^{* * *} \\
(0.035)\end{array}$ \\
\hline Age 30-39 & $\begin{array}{l}-0.024 \\
(0.036)\end{array}$ & $\begin{array}{l}0.175^{* *} \\
(0.087)\end{array}$ & $\begin{array}{l}-0.038^{*} \\
(0.022)\end{array}$ & $\begin{array}{l}0.158 \\
(0.099)\end{array}$ & $\begin{array}{l}0.085 \\
(0.104)\end{array}$ \\
\hline Age 40-49 & $\begin{array}{l}-0.092^{* * *} \\
(0.028)\end{array}$ & $\begin{array}{l}0.154^{*} \\
(0.084)\end{array}$ & $\begin{array}{l}-0.110^{* * *} \\
(0.021)\end{array}$ & $\begin{array}{l}0.143 \\
(0.097)\end{array}$ & $\begin{array}{l}0.062 \\
(0.102)\end{array}$ \\
\hline Age 50-59 & $\begin{array}{l}-0.130^{* * *} \\
(0.023)\end{array}$ & $\begin{array}{l}0.219^{* *} \\
(0.088)\end{array}$ & $\begin{array}{l}-0.137^{* * * *} \\
(0.020)\end{array}$ & $\begin{array}{l}0.124 \\
(0.096)\end{array}$ & $\begin{array}{l}0.002 \\
(0.097)\end{array}$ \\
\hline Age $60-69$ & $\begin{array}{l}-0.099^{* * *} \\
(0.033)\end{array}$ & $\begin{array}{l}0.160 \\
(0.116)\end{array}$ & $\begin{array}{l}-0.151^{* * *} \\
(0.024)\end{array}$ & $\begin{array}{l}0.147 \\
(0.101)\end{array}$ & $\begin{array}{l}-0.024 \\
(0.107)\end{array}$ \\
\hline Age $\geq 70$ & $\begin{array}{l}-0.138^{* * *} \\
(0.022)\end{array}$ & $\begin{array}{l}-0.047 \\
(0.134)\end{array}$ & $\begin{array}{l}-0.222^{* * *} \\
(0.021)\end{array}$ & $\begin{array}{l}0.051 \\
(0.101)\end{array}$ & $\begin{array}{l}0.109 \\
(0.131)\end{array}$ \\
\hline Single & $\begin{array}{l}0.080^{* * *} \\
(0.025)\end{array}$ & $\begin{array}{l}-0.177^{* * *} \\
(0.066)\end{array}$ & $\begin{array}{l}0.002 \\
(0.014)\end{array}$ & $\begin{array}{l}0.044 \\
(0.027)\end{array}$ & $\begin{array}{l}-0.009 \\
(0.036)\end{array}$ \\
\hline No of children & $\begin{array}{l}-0.001 \\
(0.010) \\
\end{array}$ & $\begin{array}{l}0.023 \\
(0.023) \\
\end{array}$ & $\begin{array}{l}-0.029^{* * *} \\
(0.008)\end{array}$ & $\begin{array}{l}-0.004 \\
(0.017)\end{array}$ & $\begin{array}{l}0.036^{* *} \\
(0.018)\end{array}$ \\
\hline $\operatorname{Pr}(Y=1 \mid$ RiskTolerance $1=1$, Male $=0)$ & 0.150 & 0.371 & 0.288 & 0.392 & 0.292 \\
\hline $\operatorname{Pr}\left(\chi^{2}\right)$ & 0.000 & 0.000 & 0.000 & 0.000 & 0.000 \\
\hline Log-Likelihood & -949.86 & -361.66 & -3825.42 & -1545.38 & -491.44 \\
\hline Pseudo- $\mathrm{R}^{2}$ & 0.329 & 0.238 & 0.256 & 0.190 & 0.249 \\
\hline No of obs. & 2,556 & 698 & 8,120 & 2,806 & 1,039 \\
\hline
\end{tabular}




\section{Table 12: Probability of investing in stocks conditional on risk tolerance}

This table summarizes the results of estimation of model (3) by means of a probit regression. The dependent variable is a binary variable equal to 1 if a household owns directly held stocks and 0 otherwise. The upper part of the table reports marginal effects of the explanatory variables on the probability of holding stocks. The effects are predicted at mean values of the explanatory variables. *, ** and ${ }^{* * *}$ correspond to $10 \%, 5 \%$ and $1 \%$ significance levels respectively. RiskTolerance 1 is a dummy variable indicating the lowest level of risk tolerance; this is the base category and is excluded from the regression equation. $\operatorname{Pr}(Y=1 \mid$ RiskTolerance $1=1$, Male $=0)$ denotes the predicted probability that a female with the lowest willingness to take financial risks owns stocks. The predicted probability is calculated at mean values of the explanatory variables.

\begin{tabular}{|c|c|c|c|c|}
\hline & Austria & Cyprus & Italy & Netherlands \\
\hline Male & $\begin{array}{l}0.030^{* *} \\
(0.015)\end{array}$ & $\begin{array}{l}0.063 \\
(0.045)\end{array}$ & $\begin{array}{l}0.074^{* * *} \\
(0.017)\end{array}$ & $\begin{array}{l}0.215 \\
(0.150)\end{array}$ \\
\hline RiskTolerance2 & $\begin{array}{l}0.090^{* * *} \\
(0.015)\end{array}$ & $\begin{array}{l}0.141^{* *} \\
(0.058)\end{array}$ & $\begin{array}{l}0.129^{* * *} \\
(0.018)\end{array}$ & $\begin{array}{l}0.298^{* *} \\
(0.151)\end{array}$ \\
\hline RiskTolerance3 & $\begin{array}{l}0.267^{* * *} \\
(0.037)\end{array}$ & $\begin{array}{l}0.079 \\
(0.062)\end{array}$ & $\begin{array}{l}0.277^{* * * *} \\
(0.031)\end{array}$ & $\begin{array}{l}0.875^{* * *} \\
(0.144)\end{array}$ \\
\hline RiskTolerance4 & $\begin{array}{l}0.301^{* * *} \\
(0.074)\end{array}$ & $\begin{array}{l}0.080 \\
(0.078)\end{array}$ & $\begin{array}{l}0.556^{* * *} \\
(0.097)\end{array}$ & $\begin{array}{l}1.166^{* * * *} \\
(0.253)\end{array}$ \\
\hline $\ln$ (Income) & $\begin{array}{l}0.081^{* * *} \\
(0.018)\end{array}$ & $\begin{array}{l}0.022^{* *} \\
(0.010)\end{array}$ & $\begin{array}{l}0.102^{* * *} \\
(0.015)\end{array}$ & $\begin{array}{l}0.179 \\
(0.117)\end{array}$ \\
\hline 2nd wealth quartile & $\begin{array}{l}0.161^{* * *} \\
(0.040)\end{array}$ & $\begin{array}{l}0.395^{* * *} \\
(0.062)\end{array}$ & $\begin{array}{l}0.269^{* *} \\
(0.135)\end{array}$ & $\begin{array}{l}0.034 \\
(0.187)\end{array}$ \\
\hline 3rd wealth quartile & $\begin{array}{l}0.297^{* * *} \\
(0.043)\end{array}$ & $\begin{array}{l}0.437^{* * *} \\
(0.061)\end{array}$ & $\begin{array}{l}0.299^{* * * *} \\
(0.115)\end{array}$ & $\begin{array}{l}0.222 \\
(0.174)\end{array}$ \\
\hline 4th wealth quartile & $\begin{array}{l}0.541^{* * *} \\
(0.043)\end{array}$ & $\begin{array}{l}0.554^{* * *} \\
(0.055)\end{array}$ & $\begin{array}{l}0.293^{* * *} \\
(0.071)\end{array}$ & $\begin{array}{l}1.138^{* * *} \\
(0.170)\end{array}$ \\
\hline Real Property & - & $\begin{array}{l}0.044 \\
(0.046)\end{array}$ & $\begin{array}{l}0.013 \\
(0.019)\end{array}$ & $\begin{array}{l}0.283^{* *} \\
(0.125)\end{array}$ \\
\hline Employed & $\begin{array}{l}-0.026 \\
(0.021)\end{array}$ & $\begin{array}{l}0.100 \\
(0.088)\end{array}$ & $\begin{array}{l}0.003 \\
(0.035)\end{array}$ & $\begin{array}{l}-0.665^{* * *} \\
(0.189)\end{array}$ \\
\hline Self-Employed & $\begin{array}{l}-0.016 \\
(0.021)\end{array}$ & $\begin{array}{l}0.016 \\
(0.052)\end{array}$ & $\begin{array}{l}-0.021 \\
(0.021)\end{array}$ & $\begin{array}{l}0.058 \\
(0.298)\end{array}$ \\
\hline Retired & $\begin{array}{l}0.015 \\
(0.026)\end{array}$ & $\begin{array}{l}0.136 \\
(0.122)\end{array}$ & $\begin{array}{l}-0.010 \\
(0.037)\end{array}$ & $\begin{array}{l}-0.283 \\
(0.216)\end{array}$ \\
\hline University & $\begin{array}{l}0.046^{* * *} \\
(0.014)\end{array}$ & $\begin{array}{l}0.176^{* * *} \\
(0.045)\end{array}$ & $\begin{array}{l}0.082^{* * *} \\
(0.025)\end{array}$ & $\begin{array}{l}0.268^{* *} \\
(0.112)\end{array}$ \\
\hline Age 30-39 & $\begin{array}{l}-0.034 \\
(0.026)\end{array}$ & $\begin{array}{l}0.176^{* *} \\
(0.087)\end{array}$ & $\begin{array}{l}0.133 \\
(0.100)\end{array}$ & $\begin{array}{l}0.212 \\
(0.349)\end{array}$ \\
\hline Age $40-49$ & $\begin{array}{l}-0.068^{* * *} \\
(0.022)\end{array}$ & $\begin{array}{l}0.155^{*} \\
(0.084)\end{array}$ & $\begin{array}{l}0.136 \\
(0.096)\end{array}$ & $\begin{array}{l}0.270 \\
(0.343)\end{array}$ \\
\hline Age 50-59 & $\begin{array}{l}-0.077^{* * *} \\
(0.019)\end{array}$ & $\begin{array}{l}0.213^{* * *} \\
(0.088)\end{array}$ & $\begin{array}{l}0.113 \\
(0.090)\end{array}$ & $\begin{array}{l}0.234 \\
(0.342)\end{array}$ \\
\hline Age 60-69 & $\begin{array}{l}-0.074^{* * *} \\
(0.024)\end{array}$ & $\begin{array}{l}0.155 \\
(0.116)\end{array}$ & $\begin{array}{l}0.113 \\
(0.095)\end{array}$ & $\begin{array}{l}0.047 \\
(0.383)\end{array}$ \\
\hline Age $\geq 70$ & $\begin{array}{l}-0.097^{* * *} \\
(0.016)\end{array}$ & $\begin{array}{l}-0.033 \\
(0.135)\end{array}$ & $\begin{array}{l}0.100 \\
(0.093)\end{array}$ & $\begin{array}{l}0.221 \\
(0.415)\end{array}$ \\
\hline Single & $\begin{array}{l}0.034^{*} \\
(0.019)\end{array}$ & $\begin{array}{l}-0.172^{* * *} \\
(0.066)\end{array}$ & $\begin{array}{l}0.026 \\
(0.020)\end{array}$ & $\begin{array}{l}0.004 \\
(0.114)\end{array}$ \\
\hline No of children & $\begin{array}{l}-0.005 \\
(0.008)\end{array}$ & $\begin{array}{l}0.024 \\
(0.022)\end{array}$ & $\begin{array}{l}0.019 \\
(0.012)\end{array}$ & $\begin{array}{l}0.120^{* *} \\
(0.055)\end{array}$ \\
\hline $\operatorname{Pr}(Y=1 \mid$ RiskTolerance $1=1$, Male $=0)$ & 0.098 & 0.369 & 0.163 & 0.097 \\
\hline $\operatorname{Pr}\left(\chi^{2}\right)$ & 0.000 & 0.000 & 0.000 & 0.000 \\
\hline Log-Likelihood & -847.13 & -362.00 & -1194.24 & -381.68 \\
\hline Pseudo- $R^{2}$ & 0.299 & 0.236 & 0.174 & 0.237 \\
\hline No of obs. & 2,556 & 698 & 2,806 & 1,039 \\
\hline
\end{tabular}




\section{Table 13: Portfolio share invested in risky assets conditional on risk tolerance}

This table summarizes the results of estimation of model (2) by means of Heckman's two-step procedure. The dependent variable is the portfolio share invested in risky financial assets. The upper part of the table reports the estimated coefficients on the explanatory variables in the main equation. The coefficients are predicted at mean values of the explanatory variables. Coefficients on the risk tolerance dummies are to be interpreted in relation to the base category RiskTolerance1 denoting the lowest level of risk tolerance. The specification of the first stage selection equation corresponds to the probit regression for the participation decision and includes the following variables: dummies for sex, risk tolerance, education, employment, family status, age groups, and wealth quartiles, logarithm of income and number of children. In the present table, we report only the estimates on wealth quartile dummies, which serve as selection equation instruments. ${ }^{*}, * *$ and ${ }^{* * *}$ correspond to $10 \%, 5 \%$ and $1 \%$ significance levels respectively.

\begin{tabular}{|c|c|c|c|c|}
\hline & Austria & Cyprus & Italy & Netherlands \\
\hline Male & $\begin{array}{l}-0.021 \\
(0.022)\end{array}$ & $\begin{array}{l}0.027 \\
(0.053)\end{array}$ & $\begin{array}{l}0.033 \\
(0.022)\end{array}$ & $\begin{array}{l}0.065 \\
(0.045)\end{array}$ \\
\hline RiskTolerance2 & $\begin{array}{l}0.071^{* * *} \\
(0.023)\end{array}$ & $\begin{array}{l}0.143^{* *} \\
(0.065)\end{array}$ & $\begin{array}{l}0.076^{* *} \\
(0.032)\end{array}$ & $\begin{array}{l}0.001 \\
(0.055)\end{array}$ \\
\hline RiskTolerance3 & $\begin{array}{l}0.146^{* * *} \\
(0.035)\end{array}$ & $\begin{array}{l}0.114^{*} \\
(0.066)\end{array}$ & $\begin{array}{l}0.123^{* * *} \\
(0.039)\end{array}$ & $\begin{array}{l}0.045 \\
(0.066)\end{array}$ \\
\hline RiskTolerance4 & $\begin{array}{l}0.229 * * * \\
(0.051)\end{array}$ & $\begin{array}{l}0.268^{* * *} \\
(0.083)\end{array}$ & $\begin{array}{l}0.335^{* * *} \\
(0.079)\end{array}$ & $\begin{array}{l}0.017 \\
(0.091)\end{array}$ \\
\hline $\ln$ (Income) & $\begin{array}{l}0.018 \\
(0.029)\end{array}$ & $\begin{array}{l}0.020^{*} \\
(0.012)\end{array}$ & $\begin{array}{l}-0.009 \\
(0.019)\end{array}$ & $\begin{array}{l}-0.029 \\
(0.042)\end{array}$ \\
\hline $\ln$ (Wealth) & $\begin{array}{l}0.025^{* *} \\
(0.013)\end{array}$ & $\begin{array}{l}-0.046^{* *} \\
(0.023)\end{array}$ & $\begin{array}{l}0.028^{* *} \\
(0.011)\end{array}$ & $\begin{array}{l}0.046^{*} \\
(0.025)\end{array}$ \\
\hline Real Property & - & $\begin{array}{l}0.080 \\
(0.053)\end{array}$ & $\begin{array}{l}-0.006 \\
(0.023)\end{array}$ & $\begin{array}{l}0.118^{* * *} \\
(0.041)\end{array}$ \\
\hline Employed & $\begin{array}{l}-0.017 \\
(0.028)\end{array}$ & $\begin{array}{l}0.207 \\
(0.131)\end{array}$ & $\begin{array}{l}0.046 \\
(0.039)\end{array}$ & $\begin{array}{l}0.023 \\
(0.067)\end{array}$ \\
\hline Self-Employed & $\begin{array}{l}0.026 \\
(0.030)\end{array}$ & $\begin{array}{l}0.077 \\
(0.054)\end{array}$ & $\begin{array}{l}-0.002 \\
(0.024)\end{array}$ & $\begin{array}{l}0.027 \\
(0.104)\end{array}$ \\
\hline Retired & $\begin{array}{l}0.015 \\
(0.036)\end{array}$ & $\begin{array}{l}0.330^{* *} \\
(0.164)\end{array}$ & $\begin{array}{l}-0.040 \\
(0.040)\end{array}$ & $\begin{array}{l}0.007 \\
(0.069)\end{array}$ \\
\hline University & $\begin{array}{l}0.015 \\
(0.018)\end{array}$ & $\begin{array}{l}0.232^{* * *} \\
(0.058)\end{array}$ & $\begin{array}{l}0.005 \\
(0.024)\end{array}$ & $\begin{array}{l}0.053 \\
(0.036)\end{array}$ \\
\hline Age 30-39 & $\begin{array}{l}0.035 \\
(0.039)\end{array}$ & $\begin{array}{l}0.320^{* * *} \\
(0.107)\end{array}$ & $\begin{array}{l}0.138^{*} \\
(0.083)\end{array}$ & $\begin{array}{l}0.061 \\
(0.106)\end{array}$ \\
\hline Age $40-49$ & $\begin{array}{l}-0.011 \\
(0.039)\end{array}$ & $\begin{array}{l}0.268^{* * *} \\
(0.102)\end{array}$ & $\begin{array}{l}0.148^{*} \\
(0.082)\end{array}$ & $\begin{array}{l}0.140 \\
(0.106)\end{array}$ \\
\hline Age 50-59 & $\begin{array}{l}-0.040 \\
(0.043)\end{array}$ & $\begin{array}{l}0.293^{* * *} \\
(0.109)\end{array}$ & $\begin{array}{l}0.156^{*} \\
(0.082)\end{array}$ & $\begin{array}{l}0.130 \\
(0.107)\end{array}$ \\
\hline Age 60-69 & $\begin{array}{l}0.005 \\
(0.048)\end{array}$ & $\begin{array}{l}0.271^{* *} \\
(0.138)\end{array}$ & $\begin{array}{l}0.264^{* * *} \\
(0.085)\end{array}$ & $\begin{array}{l}0.134 \\
(0.119)\end{array}$ \\
\hline Age $\geq 70$ & $\begin{array}{l}-0.031 \\
(0.056)\end{array}$ & $\begin{array}{l}0.063 \\
(0.170)\end{array}$ & $\begin{array}{l}0.156^{*} \\
(0.084)\end{array}$ & $\begin{array}{l}0.151 \\
(0.126)\end{array}$ \\
\hline Single & $\begin{array}{l}0.024 \\
(0.024)\end{array}$ & $\begin{array}{l}-0.157 \\
(0.126)\end{array}$ & $\begin{array}{l}0.050^{* *} \\
(0.022)\end{array}$ & $\begin{array}{l}0.068^{*} \\
(0.039)\end{array}$ \\
\hline No of children & $\begin{array}{l}-0.021^{* *} \\
(0.011)\end{array}$ & $\begin{array}{l}0.021 \\
(0.025)\end{array}$ & $\begin{array}{l}0.018 \\
(0.013)\end{array}$ & $\begin{array}{l}0.009 \\
(0.018)\end{array}$ \\
\hline Constant & $\begin{array}{l}-0.300 \\
(0.375) \\
\end{array}$ & $\begin{array}{l}-0.452 \\
(0.440) \\
\end{array}$ & $\begin{array}{l}-0.088 \\
(0.325) \\
\end{array}$ & $\begin{array}{l}-0.236 \\
(0.593) \\
\end{array}$ \\
\hline \multicolumn{5}{|c|}{ Selection Equation Instruments } \\
\hline 2nd wealth quartile & $\begin{array}{l}0.858^{* * *} \\
(0.139)\end{array}$ & $\begin{array}{l}1.039^{* * *} \\
(0.171)\end{array}$ & $\begin{array}{l}0.724^{* *} \\
(0.361)\end{array}$ & $\begin{array}{l}1.045^{* * *} \\
(0.222)\end{array}$ \\
\hline 3rd wealth quartile & $\begin{array}{l}1.442^{* * *} \\
(0.138)\end{array}$ & $\begin{array}{l}1.174^{* * * *} \\
(0.172)\end{array}$ & $\begin{array}{l}1.209^{* * *} \\
(0.352)\end{array}$ & $\begin{array}{l}1.644^{* * *} \\
(0.218)\end{array}$ \\
\hline 4th wealth quartile & $\begin{array}{l}2.172^{* * *} \\
(0.141)\end{array}$ & $\begin{array}{l}1.534^{* * * *} \\
(0.180)\end{array}$ & $\begin{array}{l}1.641^{* * *} \\
(0.352)\end{array}$ & $\begin{array}{l}2.453^{* * *} \\
(0.223)\end{array}$ \\
\hline$\lambda$ & $\begin{array}{l}0.077^{* *} \\
(0.036)\end{array}$ & $\begin{array}{l}0.398^{* * *} \\
(0.132)\end{array}$ & $\begin{array}{l}0.186^{* * *} \\
(0.063)\end{array}$ & $\begin{array}{l}0.097 \\
(0.075)\end{array}$ \\
\hline$\rho$ & 0.392 & 0.924 & 0.640 & 0.349 \\
\hline$\sigma$ & 0.197 & 0.431 & 0.290 & 0.279 \\
\hline No of obs. & 2,556 & 698 & 2,806 & 1,012 \\
\hline No of censored obs. & 1,937 & 406 & 1,630 & 703 \\
\hline
\end{tabular}




\section{Table 14: Portfolio share invested in stocks conditional on risk tolerance}

This table summarizes the results of estimation of model (2) by means of Heckman's two-step procedure. The dependent variable is the portfolio share invested in directly held stocks. The upper part of the table reports the estimated coefficients on the explanatory variables in the main equation. The coefficients are predicted at mean values of the explanatory variables. Coefficients on the risk tolerance dummies are to be interpreted in relation to the base category RiskTolerance1 denoting the lowest level of risk tolerance. The specification of the first stage selection equation corresponds to the probit regression for the participation decision and includes the following variables: dummies for sex, risk tolerance, education, employment, family status, age groups, and wealth quartiles, logarithm of income and number of children. In the present table, we report only the estimates on wealth quartile dummies, which serve as selection equation instruments. ${ }^{*}, * *$ and ${ }^{* * *}$ correspond to $10 \%, 5 \%$ and $1 \%$ significance levels respectively.

\begin{tabular}{|c|c|c|c|c|}
\hline & Austria & Cyprus & Italy & Netherlands \\
\hline Male & $\begin{array}{l}-0.015 \\
(0.022)\end{array}$ & $\begin{array}{l}0.023 \\
(0.052)\end{array}$ & $\begin{array}{l}0.084 \\
(0.053)\end{array}$ & $\begin{array}{l}0.125^{* *} \\
(0.062)\end{array}$ \\
\hline RiskTolerance2 & $\begin{array}{l}0.034 \\
(0.024)\end{array}$ & $\begin{array}{l}0.149^{* *} \\
(0.065)\end{array}$ & $\begin{array}{l}0.209^{* * *} \\
(0.070)\end{array}$ & $\begin{array}{l}-0.083 \\
(0.063)\end{array}$ \\
\hline RiskTolerance3 & $\begin{array}{l}0.061^{*} \\
(0.034)\end{array}$ & $\begin{array}{l}0.118^{*} \\
(0.065)\end{array}$ & $\begin{array}{l}0.396^{* * *} \\
(0.108)\end{array}$ & $\begin{array}{l}0.025 \\
(0.071)\end{array}$ \\
\hline RiskTolerance4 & $\begin{array}{l}0.142^{* * *} \\
(0.049)\end{array}$ & $\begin{array}{l}0.264^{* * *} \\
(0.082)\end{array}$ & $\begin{array}{l}0.776^{* * *} \\
(0.184)\end{array}$ & $\begin{array}{l}0.001 \\
(0.100)\end{array}$ \\
\hline $\ln ($ Income $)$ & $\begin{array}{l}0.031 \\
(0.028)\end{array}$ & $\begin{array}{l}0.024^{* * *} \\
(0.012)\end{array}$ & $\begin{array}{l}0.104^{*} \\
(0.053)\end{array}$ & $\begin{array}{l}0.014 \\
(0.044)\end{array}$ \\
\hline $\ln$ (Wealth) & $\begin{array}{l}-0.005 \\
(0.012)\end{array}$ & $\begin{array}{l}-0.049^{* *} \\
(0.023)\end{array}$ & $\begin{array}{l}-0.018 \\
(0.017)\end{array}$ & $\begin{array}{l}0.031 \\
(0.026)\end{array}$ \\
\hline Real Property & - & $\begin{array}{l}0.078 \\
(0.053)\end{array}$ & $\begin{array}{l}0.040 \\
(0.041)\end{array}$ & $\begin{array}{l}0.144^{* * *} \\
(0.055)\end{array}$ \\
\hline Employed & $\begin{array}{l}0.027 \\
(0.027)\end{array}$ & $\begin{array}{l}0.201 \\
(0.131)\end{array}$ & $\begin{array}{l}0.020 \\
(0.071)\end{array}$ & $\begin{array}{l}-0.079 \\
(0.082)\end{array}$ \\
\hline Self-Employed & $\begin{array}{l}0.001 \\
(0.030)\end{array}$ & $\begin{array}{l}0.076 \\
(0.054)\end{array}$ & $\begin{array}{l}-0.019 \\
(0.046)\end{array}$ & $\begin{array}{l}0.005 \\
(0.127)\end{array}$ \\
\hline Retired & $\begin{array}{l}0.079^{* *} \\
(0.037)\end{array}$ & $\begin{array}{l}0.319^{*} \\
(0.163)\end{array}$ & $\begin{array}{l}-0.031 \\
(0.076)\end{array}$ & $\begin{array}{l}0.029 \\
(0.075)\end{array}$ \\
\hline University & $\begin{array}{l}-0.006 \\
(0.017)\end{array}$ & $\begin{array}{l}0.228^{* * *} \\
(0.057)\end{array}$ & $\begin{array}{l}0.072 \\
(0.049)\end{array}$ & $\begin{array}{l}0.025 \\
(0.041)\end{array}$ \\
\hline Age 30-39 & $\begin{array}{l}0.009 \\
(0.041)\end{array}$ & $\begin{array}{l}0.315^{* * *} \\
(0.106)\end{array}$ & $\begin{array}{l}0.140 \\
(0.170)\end{array}$ & $\begin{array}{l}-0.112 \\
(0.147)\end{array}$ \\
\hline Age $40-49$ & $\begin{array}{l}-0.012 \\
(0.040)\end{array}$ & $\begin{array}{l}0.262^{* * *} \\
(0.101)\end{array}$ & $\begin{array}{l}0.144 \\
(0.168)\end{array}$ & $\begin{array}{l}-0.146 \\
(0.147)\end{array}$ \\
\hline Age 50-59 & $\begin{array}{l}-0.030 \\
(0.042)\end{array}$ & $\begin{array}{l}0.290^{* * *} \\
(0.108)\end{array}$ & $\begin{array}{l}0.117 \\
(0.166)\end{array}$ & $\begin{array}{l}-0.152 \\
(0.147)\end{array}$ \\
\hline Age 60-69 & $\begin{array}{l}0.007 \\
(0.048)\end{array}$ & $\begin{array}{l}0.264^{*} \\
(0.137)\end{array}$ & $\begin{array}{l}0.231 \\
(0.171)\end{array}$ & $\begin{array}{l}-0.183 \\
(0.160)\end{array}$ \\
\hline Age $\geq 70$ & $\begin{array}{l}-0.009 \\
(0.057)\end{array}$ & $\begin{array}{l}0.084 \\
(0.169)\end{array}$ & $\begin{array}{l}0.143 \\
(0.170)\end{array}$ & $\begin{array}{l}-0.171 \\
(0.163)\end{array}$ \\
\hline Single & $\begin{array}{l}0.044^{*} \\
(0.023)\end{array}$ & $\begin{array}{l}-0.149 \\
(0.125)\end{array}$ & $\begin{array}{l}0.042 \\
(0.041)\end{array}$ & $\begin{array}{l}0.047 \\
(0.046)\end{array}$ \\
\hline No of children & $\begin{array}{l}-0.011 \\
(0.011)\end{array}$ & $\begin{array}{l}0.023 \\
(0.025)\end{array}$ & $\begin{array}{l}0.043^{*} \\
(0.025)\end{array}$ & $\begin{array}{l}0.020 \\
(0.021)\end{array}$ \\
\hline Constant & $\begin{array}{l}-0.153 \\
(0.378)\end{array}$ & $\begin{array}{l}-0.445 \\
(0.441)\end{array}$ & $\begin{array}{l}-1.611^{*} \\
(0.957)\end{array}$ & $\begin{array}{l}-0.457 \\
(0.618)\end{array}$ \\
\hline \multicolumn{5}{|c|}{ Selection Equation Instruments } \\
\hline 2nd wealth quartile & $\begin{array}{l}0.740^{* * *} \\
(0.158)\end{array}$ & $\begin{array}{l}1.037^{* * *} \\
(0.171)\end{array}$ & $\begin{array}{l}0.847 \\
(0.541)\end{array}$ & $\begin{array}{l}0.969^{* * *} \\
(0.295)\end{array}$ \\
\hline 3rd wealth quartile & $\begin{array}{l}1.215^{* * *} \\
(0.154)\end{array}$ & $\begin{array}{l}1.158^{* * *} \\
(0.172)\end{array}$ & $\begin{array}{l}1.022^{*} \\
(0.531)\end{array}$ & $\begin{array}{l}1.235^{* * * *} \\
(0.289)\end{array}$ \\
\hline 4th wealth quartile & $\begin{array}{l}1.982^{* * *} \\
(0.155)\end{array}$ & $\begin{array}{l}1.525^{* * * *} \\
(0.180)\end{array}$ & $\begin{array}{l}1.314^{* *} \\
(0.531)\end{array}$ & $\begin{array}{l}2.199 * * * \\
(0.288)\end{array}$ \\
\hline$\lambda$ & $\begin{array}{l}0.047 \\
(0.036)\end{array}$ & $\begin{array}{l}0.389 * * * \\
(0.131)\end{array}$ & $\begin{array}{l}0.476^{* * *} \\
(0.151)\end{array}$ & $\begin{array}{l}0.135^{*} \\
(0.074)\end{array}$ \\
\hline$\rho$ & 0.283 & 0.914 & 1.000 & 0.541 \\
\hline$\sigma$ & 0.166 & 0.426 & 0.476 & 0.249 \\
\hline No of obs. & 2,556 & 698 & 2,806 & 1,012 \\
\hline No of censored obs. & 2,093 & 408 & 2,214 & 838 \\
\hline
\end{tabular}

